\title{
Participatory Accountability and Collective Action: Experimental Evidence from Albania
}

\author{
Abigail Barr \\ University of Nottingham
}

Truman Packard

The World Bank

January 2014

\begin{abstract}
It has been argued that accountability is a public good that only citizens can provide. Governments can put institutions in place that allow citizens to hold public servants to account, but citizens must participate in those institutions if accountability is to be achieved. Thus, citizens face a social dilemma - participate in holding public servants to account at a cost in terms of time and effort or free ride, i.e. do not participate, while benefiting from the efforts of those who do. If this characterization of accountability is valid, we would expect more cooperatively inclined citizens to participate in accountability institutions, while the less cooperatively inclined do not. We test the validity of this characterization by investigating the correlation between individual behavior in a simple public goods game and their participation in local and national accountability institutions in Albania. We involve a nationally representative sample of 1800 adults with children in primary school. We find significant correlations between cooperativeness and participation in school accountability institutions and national elections, both at the individual level and the district level. These correlations are robust to the introduction of many controls in the analysis and, in the case of national elections, to the use of official election turn-out statistics in place of self-reported turn-out.
\end{abstract}

JEL CODES: C93, D72, H4, O12

KEYWORDS: accountability; participation; elections; collective action; public good game

${ }^{*}$ Corresponding author. Department of Economics, Southern Methodist University, Dallas, Texas. Email: dserra@ smu.edu. 


\section{Introduction}

There is general agreement that participatory institutions are a necessary condition for accountability, especially where top-down institutions are malfunctioning or missing. Under the participatory approach, governments put institutions in place that allow citizens to play an active role in keeping service providers accountable. This is done by connecting citizens to policy makers through the instrument of the vote, i.e. by relying on a "long route" to accountability, and/or by connecting citizens directly to service providers, i.e. by creating a "short route" to accountability. ${ }^{1}$ Recently, empirical investigations of the effectiveness of participatory institutions have been conducted in many different countries. In education, reforms aiming to improve accountability by increasing parental participation in schools - also called schoolbased management reforms (e.g. Banerjee et al, 2010; Blimpo and Evans, 2011; Duflo et al., 2011; Pradhan et al. 2011) provide mixed evidence of success, yet the reasons for the contrasting results obtained in different societies are unclear.

One possible explanation for the mixed evidence lies in heterogeneities in individuals' and communities' willingness and ability to overcome collective action problems. The first step toward successful participatory accountability is individual participation, but participation itself is a social dilemma; it involves a private cost, yet it benefits others, and its efficacy requires a significant number of participants. Hence, participation might be subject to "free-riding" (Samuelson, 1954; Olson, 1965; Grossman and Hart, 1980; Ostrom, 1998) and it follows that effective participatory accountability may depend, at least partly, on individuals' propensity to cooperate with others for the common good. ${ }^{2}$ This is an important issue that has been overlooked by the empirical literature. Theoretical insights have been provided by studies on voter turnout. Seminal work in political science (Downs, 1957) suggested that voting is an irrational act because the expected benefit of voting, i.e. the probability that one's vote is pivotal multiplied by the differential benefit generated by the preferred electoral outcome, is lower than the cost of voting. Later studies showed that the paradox of voting could be solved by taking into account the intrinsic benefits, such as the satisfaction from compliance with the ethic of voting (Riker and Ordeshook, 1968), and/or the benefits that voting generates for society. Palfrey and Rosenthal (1983, 1985) were the first to suggest that the decision to go to vote has the characteristics of a "participation game", i.e., given that the electoral outcome itself is non-excludable and non-rival and the act of voting involves a private cost, turning out to vote has the characteristics of a collective action problem.

\footnotetext{
${ }^{1}$ Accountability refers to "the act of holding public officials and service providers answerable for processes and outcomes, and imposing penalties if specified outputs and outcomes are not delivered" (Lewis and Petterson, 2009). The long- and short-rote accountability terminology was introduced by the World Bank (see World Bank, 2004).

${ }^{2}$ As stated by Platteau (2008), in order for participation to be effective, "community members must be able to use the available information jointly in a way that creates some action, that is, they must be able to come together, share and discuss their knowledge and be ready to act on it" (p. 128).
} 
In this paper, we investigate whether, both at the individual- and the community-level, willingness to cooperate with others for the common good is associated with parents' willingness to participate in school accountability institutions, i.e., a "short route" to accountability, and to vote in national elections, i.e., a "long route" to accountability. We therefore test whether a single behavioral tendency drives decisionmaking in two contexts that, while different in scale and specific purpose, are both accountability-related and present individuals with a dilemma taking the form of a participation game. We conduct our study in Albania, a country that slowly transitioned from communism to a parliamentary democracy in the 1990s, and that, like other new democracies in Eastern Europe and the Balkans, is characterized by limited active civil society, owing to policies implemented by former regimes to either eliminate groups mediating between the individual and the state or control groups in order to prevent organized opposition to the regime (Lipset, 1994). ${ }^{3}$ Our analysis is based on a comprehensive survey of 1800 parents randomly selected from a nationally representative sample of 180 primary schools.

Measuring individuals' willingness to cooperate with others for the common good is challenging. Attitudinal survey measures, such as the standard GSS trust variable, are likely to suffer from a hypothetical or cheap-talk bias, i.e., individuals' answers might not be truthful when they refer to hypothetical situations or past events that cannot be verified by the surveyor. ${ }^{4}$ Survey questions referring to actions in everyday life, such as membership in organizations, are less likely to suffer from these biases as they are, in principal, verifiable. However, they are likely to suffer from significant noise due to unobserved heterogeneity in the decision-making context. ${ }^{5} \mathrm{We}$ overcome these measurement challenges by involving our subjects in a simplified version of the public goods game first introduced by Cardenas and Jaramillo (2007), thus generating a direct measure of individual willingness to cooperate with others for the common good. We correlate cooperativeness in the game with the decision to participate in both a short route to accountability, i.e. the decision to participate in the election of parent class representatives, and a long route to accountability, i.e., the decision to vote in the most recent parliamentary elections. For the latter variable we use both self-reported voting at the individual level, and official records of voter turnout at the district level.

Experimental studies employing public goods games have shown that individuals vary markedly in their willingness to cooperate with others for the common good (see Isaac and Walker, 1988; Fehr and Gachter, 2000; Fischbacher et al., 2001; Bowles and Gintis, 2002; Fischbacker and Gachter, 2010, among

\footnotetext{
${ }_{4}^{3}$ For instance, in Albania religious practices were officially banned in 1967, to be reinstated in the 1990s.

${ }^{4}$ This might be due to what Carpenter (2002) refers to as the idealized persona bias, i.e. a desire to appear as the person one would like to be rather than what they are, and/or the surveyor effect, i.e. the desire to answer in accordance to what one thinks the surveyor would like to hear or see.

${ }^{5}$ For general discussions of the limitations of attitudinal survey measures, see Bertrand and Mullainathan (2001), Manski (2004) and Delavande et al (2011). For assessments of attitudinal survey measures based on a comparison with the corresponding experimental measures, see Ahn et al. (2003), Ashraf et al. (2003), Cardenas et al. (2013), Gaechter et al. (2004) and Glaeser et al. (2000).
} 
others). ${ }^{6}$ Moreover, a few additional experimental studies (Henrich et al., 2005; Herrmann et al., 2008; Gaechter et al., 2010) have highlighted that a significant proportion of the variation in individuals' willingness to cooperate occurs at the community or society level. ${ }^{7}$ The nature and scale of our survey sampling allows us to investigate whether and how the distribution of willingness to cooperate varies spatially within Albania. Contrary to most experimental studies conducted in the lab or in the field, we involved a large representative sample of non-student adults - a total of 1800 individuals - covering the entire Albanian territory.

We find that individuals who behave cooperatively in the public goods game are significantly more likely to participate in the election of parent class representatives who go on to elect parent representatives to the school board. This relationship remains significant after controlling for the degree to which parents are informed about aspects of local accountability in schools. Moreover, parents who behave cooperatively in the public goods game are more likely to vote in national elections, according to both self-reported voting and district-level records of official turnout. Our data show significant variation in both participation and cooperativeness across districts, and district-level analysis confirms that districts characterized by a higher proportion of cooperative parents have both a higher degree of participation in school accountability and a higher turnout in the 2009 elections according to official records. Our results are robust to changes in the context in which participation is defined, the scale of the analysis and the empirical specification.

The finding that the same behavioral driver applies to two participation contexts - a local one and a national one - that differ in scale, specific purpose, associated costs and benefits, and the extent to which individual participation decisions are visible to others, is remarkable. It indicates that the collective-action characteristic of accountability systems is fundamentally important and suggests that interventions aimed at increasing individual cooperativeness could succeed in improving both participation in local accountability institutions and civic engagement at the national level.

Finally, we note that our study also contributes to the literature on the external validity of public goods experiments by providing evidence of a correlation between behavior within a lab-type public goods game and behavior in naturally occurring decision-contexts within which inter-personal cooperation is also salient. While cooperative tendencies in public goods experiments have been shown to correlate with the management of forest commons by forest user groups in Ethiopia (Rustagi et al. 2010),

\footnotetext{
${ }^{6}$ For comprehensive reviews of the experimental literature relating to behavior in public goods experiments see Ledyard (1995) and Chaudhuri (2011).

${ }^{7}$ One important society characteristic that has been shown to be negatively correlated with individual contributions to a public good (Habyarimana et al. 2007), participation in community activities (Alesina and La Ferrara, 2000), community-based monitoring of public service providers (Bjorkman and Svensson, 2010), and local public good provision (Miguel and Gugerty, $2004)$ is ethnic fragmentation. Neighborhood social and economic inequalities have also been shown to matter for urban violence (Morenoff, Sampson and Raudenbush, 2001) and collective civic action (Sampson et al., 2005).
} 
with Japanese fishermen's productivity when pooling their catches with other fishermen (Carpenter and Seki, 2011), and Brazilian fishermen's propensity not to over-exploit common fishing grounds (Fehr and Leibbrandt, 2011), this is, to the best of our knowledge, the first study providing evidence of a correlation between individuals' behavior in a public goods experiment and their willingness to cooperate with others in participatory accountability systems and civic engagement.

The paper is arranged as follows. Section 2 describes the Albanian context focusing, in particular, on the education sector. Section 3 describes the school survey and the public goods experiment. Section 4 presents descriptive statistics about the surveyed parents and explores individual and community characteristics affecting parents' cooperativeness in the public goods game. Section 5 reports our empirical results, and Section 6 provides some conclusions.

\section{The Albanian context}

\subsection{A new democracy}

Albania was the last country in Europe to participate in the "third wave of democracy" (Huntington, 1991). Despite the high levels of economic growth experienced during the democratic transition, Albania remains one of the poorest in Europe, with a per capita GDP of 8,000 USD (2010 international PPP \$). Albania's relative underdevelopment has been attributed, in part, to the slowness of its transition to democracy relative to other Eastern European countries. The new democratic constitution was adopted in 1998. Since then, there have been three parliamentary elections - not without controversies concerning electoral fraud, protests and boycotts by the losing party. In each, voter turnout has been around $50 \%$. Data from the 2010 Life in Transition Survey (LiTS) show that about 70 per cent of Albanians do not think that free and fair elections exist in their country. ${ }^{8}$

Albania's slow transition to democracy has been attributed to the unique characteristics of its communist regime: its isolation from other countries, including the Soviet bloc, for half a century; the elimination of intellectuals (including western-educated Albanians); the abolition of religious practices; and the harsh persecution of opponents to the regime. With the end of communism, a new era began. One of the consequences of the repression of civic organizations during the communist regime is the lack of an active civil society, i.e. formal and informal organizations (with or without political objectives) and voluntary community participation, in the newly formed democracy of Albania. ${ }^{9}$ This is consistent with

\footnotetext{
${ }^{8}$ For further details see: http://www.ebrd.com/pages/research/publications/special/transitionII.shtml

${ }^{9}$ According to Talifi (2008), most of the efforts to build a civil society in Albania - primarily undertaken by donor-based NGOs - have relied on awareness campaigns and capacity building, and have emphasized the importance of an informed society and electoral base. The inherent shortcoming of this approach is the assumption that by informing people about democratic and participatory institutions, participation will follow. Talifi (2008) argues that "this approach of civil society has decreased rather
} 
the existing evidence that totalitarian regimes destroy social capital (see Paldan and Svendsen, 2000; Rose, 1993; Smolar, 1996).

Geographically, Albania is subdivided into twelve counties and thirty-six districts. Culturally, the country is characterized by a North-South divide, with the North traditionally relying on a patriarchal tribal system and being more isolated than the market-oriented South (Doll, 2003; Shala, 1997; Lawson and Saltmarshe, 2000). ${ }^{10}$ The North-South cultural division also reflects a strong political polarization: the Northern regions are traditionally and historically allied to the Democratic Party (in office since 2005) while the Southern regions support the Socialist Party (in office from 1997 to 2005). ${ }^{11}$ Besides the northsouth distinction, Albania can be further divided in four main geographical areas - Coastal, Centre, Mountain and Tirana, with the Mountain region being the most remote and poorest and the Coastal region being the most developed. Migration from the Mountain region to the Coast and Tirana has increased markedly over the last 15 years, and explains the increasing heterogeneity in the coastal population.

\subsection{The education sector}

In the years following the transition, there was a sharp decline in the coverage and quality of social services. School enrolment rates dropped and, in some areas, have still not recovered to pre-transition levels. Although $99 \%$ of the adult population is literate, the quality of education is low, as shown by Albania's performance in the 2009 Program for International Student Assessment (PISA). More than 50\% of 15 years old students found it difficult "to use continuous texts unless the texts are short and clearly sign-posted; and even with such texts, they are unlikely to be able to do more than identify a main idea or find explicitly stated information." 12

The Ministry of Education and Science (MoES) is the central government body responsible for implementing education policies and managing the education system. This responsibility is exercised by staff in the MoES and in twelve administration entities (REDs) functioning at the county level. The institutional framework currently in place relies on a system that assigns the task of monitoring teachers and imposing penalties for under-performance to administrative units, i.e., the twelve REDs, that are not directly held to account by service recipients, i.e., it relies on top-down accountability. ${ }^{13}$ However, the

\footnotetext{
than increased public participation in the process, because simply telling people to participate is not a good enough approach to contribute to the democratization of the country".

${ }^{10}$ The North and the South also differ in the main dialects spoken, i.e. the Gheg in the North and the Tosk in the South.

${ }^{11}$ Since 1997, Albania has relied on a proportional voting system. The Democratic Party (DP) and the Socialist Party (SP) are the two dominant parties. In the 2009 elections, the DP obtained $40.18 \%$ of votes, all from the North, and the PD obtained $40.85 \%$ of votes, all from the South. As shown by Gërxhani and Schram (2000, 2009), Albanian politics is dominated by clientelism and patronage, whereby the party in power favors its own supporting regions over the rest of the country, and voters support their "own" party no matter what.

${ }^{12}$ See http://www.portugal.gov.pt/pt/GC18/Documentos/ME/PISA_2009_1.pdf

${ }^{13}$ The existing top-down system is functioning poorly in terms of accountability. According to our school survey, it is very common for teachers to believe that there are no negative repercussions to bad performance: about $50 \%$ indicated that they would
} 
MoES has recently been promoting community engagement in school governance structures through parent committees and school boards. Parent committees are composed of elected parent class representatives, and school boards are composed of two or more (depending on the size of the school) parent representatives, one teacher representative, a student representative, a community representative and a RED representative. Parent class representatives are elected by the parents of pupils in their respective classes at the beginning of the school year. They, then, elect representatives from amongst themselves to the school boards.

While school boards have always existed, they have recently been given greater responsibilities for school governance. The main functions of the School Board are to examine and approve (by voting) the school's mid-term and annual plans and the school's annual financial report. The board also has decisional power for the adoption of curricula and textbooks, as well as the school's budget relating to contributions from the community or other donors, or revenues from school activities. School Board members may also discuss problems relating to the performance of teachers, or school directors, following complaints from parents, students, or teachers. Since 2008, the school director is not a member of the school board and, although he/she can still participate in meetings, he/she cannot vote.

\section{The School Stakeholder Survey}

We conducted the Albania School Stakeholder Survey as part of the World Bank's Accountability for Better Governance Program. The survey was primarily aimed at investigating the role that parents play in the institutional framework within which primary schools currently operate. We complemented our survey data with data from official records on district-level voter turnout in the 2009 parliamentary elections.

\subsection{Survey design and implementation}

The data collection took place between October and December 2009 in a representative sample of 180 primary schools, offering grades one to nine. The sampling strategy relied on stratification at the district level; the number of schools randomly selected to participate in the survey in each district depended on the number of pupils attending primary school in that district. ${ }^{14}$ For each school, three and seven students were randomly selected from grades three and six respectively. Then, the parents of the selected pupils

not receive a penalty if they underperformed. Moreover, those who thought they would be penalized were unclear with respect to what kind of penalty they would receive.

${ }^{14}$ The sample was drawn from the list of all public primary schools in Albania. There are 2691 public basic level schools in Albania, of which 12 percent are located in urban areas. Out of the 2691 primary schools, we defined as "eligible" those schools with five or more pupils in grade three, and ten or more pupils in grade six. Only 1623 of the 2691 primary schools in the complete list met this eligibility criterion. However, only 9 percent of all Albanian public primary school pupils attend ineligible schools. The list of eligible schools was then divided into 36 strata according to district and either six, four or two schools was randomly sampled from each, the number depending on the number of pupils attending primary school in the district. Since the district of Tirana contained twice the percentage of pupils as well as twice the number of eligible schools, it was divided into two strata, Tirana Municipality and Tirana District, leading to a total of 37 strata. 
were invited to participate in a workshop that took place in the school premises. The MoES assisted in the implementation of the survey by demanding the full cooperation of school directors and teachers in the sampled schools. Invitations to parents were made via messages carried home by the selected students and by phone, after acquiring phone numbers from school records. The invitations emphasized the show-up fees that participants would receive upon arrival to the workshop. Either one of the parents, but not both, could participate in the survey and experiment. The parent who participated in the study was self-selected, which is not ideal from a scientific viewpoint, yet is reflects a similar self-selection process that takes place when parents have to decide whether and who will go to their kids' school to participate in the election of class parent representatives. About $57 \%$ of our survey participants were female.

Financial incentives, i.e., monetary payoffs from the behavioral games, and the enumerators' willingness to visit the reluctant parents in person allowed us to achieve a 100 per cent parent participation rate. Besides the parents of the selected pupils, one teacher of the third graders and four teachers of the sixth graders were randomly selected to participate in the survey and experiments together with the parents of the selected pupils. Therefore, in each school we collected data from ten parents and five teachers, leading to total sample sizes of 1800 parents and 900 teachers.

\subsection{The public good game}

In order to generate a direct measure of individuals' propensities to coordinate and cooperate with others to solve collective action problems, we undertook a laboratory experiment conducted in the field. Experiments facilitate the measurement of individuals' values, beliefs and preferences that are difficult to capture using surveys. Experimentally generated measures of individual preferences for cooperation in the context of a public goods game have been shown to correlate with individuals' behavior in everyday life in a number of contexts. Fehr and Leibbrandt (2011) found that Brazilian fishermen who behaved more selfishly in a public goods game were more likely to over-exploit common fishing grounds. Carpenter and Seki (2011) found that Japanese fishermen's behavior in a public goods game predicted their productivity when pooling their catches with other fishermen. Rustagi et al. (2010) found that forest users groups that show higher levels of conditional cooperation in a public goods game are more successful in forest commons management. ${ }^{15}$ Public goods games have also been used following randomized interventions to identify changes in individuals' attitudes and preferences. For instance, Fearon et al. (2011) and Casey et al. (2012) employed a public goods game to assess the impact of a community driven development initiative on individuals' ability to overcome collective action problems

\footnotetext{
${ }^{15}$ A number of other studies find significant correlations between behavior in laboratory experiments other than the public goods game and behavior outside the lab. See for instance: Carpenter and Myers (2010); Karlan, 2005; Barr and Serneels, 2009; Serra et al., 2011. For a recent review of studies that find correlations between behavior in laboratory experiments and out-of-the-lab behavior see Camerer (2014).
} 
respectively in Liberia and Sierra Leone. Similarly, Attanasio et al. (2009) employed a public goods game to compare individuals' propensities to cooperate with each other in two communities in Colombia, one that had received conditional cash transfers for over two years, and one that had not.

We adapted the binary public goods game of Cardenas and Jaramillo (2007) to the Albanian context. All surveyed parents and teachers participated in the experiment on their school premises. Thus, each experimental session included 15 subjects. Each participant was given a voucher and had to decide whether to invest their voucher either in a group account or a private account. If an individual invested in the group account, he/she would get 100 LEK plus 100 LEK multiplied by the number of other participants investing in the group account: ${ }^{16} E_{i}^{G}=100+100 N_{j}^{G}$, with $j \neq i$, where $E_{i}^{G}$ indicates the earnings of individual $i$ from investing in the group account, and $N_{j}^{G}$ indicates the total number of other participants who invested in the group account. If an individual invested in the private account, he/she would get 500 LEK plus 100 LEK multiplied by the number of other participants investing in the group account: $E_{i}^{P}=500+100 N_{j}^{G}$, with $j \neq i$. It follows that the marginal per capita return ratio (MPCR) from investing in the group account was set equal to 0.20 , and the experimental parameters were such that at least 5 investors in the group account were needed for each investor to earn at least as much as he/she would earn by investing in the private account with all the other participants doing likewise.

The dominant strategy is to invest in the private account, since it yields higher earnings no matter what the others do. Consequently, the Nash equilibrium is that everyone invests in the private account and earns 500 LEK. In stark contrast, in the social optimum everyone invests in the group account and earns 1500 LEK.

Each experimental session was conducted using a large classroom with all fifteen subjects seated at well-spaced desks. On arrival, each subject was registered and asked to blindly pick a badge bearing a number. Following registration, each subject was invited to sit at the desk bearing their badge number. Then the experiment was introduced. ${ }^{17} \mathrm{~A}$ white board was used to explain all possible configurations of individual payoffs conditional on the investment decisions of the other participants. Two field researchers explained the game to all the participants. One field researcher read the written instructions, provided in Appendix, aloud to the group while the other wrote the corresponding numerical examples on the white board. The field researchers were trained to spend as much time as needed explaining the rules of the game and proceed to the decision-making phase of the experiment only when all the subjects showed a clear understanding of the rules of the game. Vouchers were then distributed among participants. Each voucher bore a letter P (for Private Account) and the letter G (for Group Account). Participants were

\footnotetext{
${ }^{16}$ At the time of the experiment, 1000 LEK corresponded to the daily wage of the average Albanian.

${ }^{17}$ Subjects also played as a standard Dictator Game (DG) and a third-party punishment. The behavior of parents and teachers in the DG and TPP games is not relevant for the purpose of this paper. For a full description of the Albania School Stakeholder survey and lab experiments, see Serra, Barr and Packard (2011).
} 
asked to circle the letter corresponding to the account in which they wished to invest their voucher. The game was played only once, and there was no communication among participants. ${ }^{18}$ The implementation of the game took between 30 and 50 minutes. However, the experimental sessions in full, including registration, implementation of all games, computation of payoffs and payment of participants, lasted between 3 and 4 hours. The same experimental protocol was followed in all schools, with the exception of one feature of the design; in half of the schools the investment in the group account was explained by using an example relating to the education sector and in the other half it was explained by using an example relating to farming. ${ }^{19}$

\section{The data}

\subsection{Individual characteristics}

We collected data on parents' demographics as well as their involvement in the school accountability system, i.e. whether they participated in the latest elections of parent class representatives, which occurred in September 2009, i.e. between 2 and 8 weeks before the data collection. We also elicited data on the degree to which each parent was informed about the existence of local accountability institutions, and their involvement in other aspects of their children's education, such as the number of meetings with the head teacher in the previous semester and how often they helped their children with homework. In designing the School Stakeholder Survey, we purposely replicated some relevant 2008 Albanian Living Standards Measurement Survey (LSMS) ${ }^{20}$ questions concerning education and social engagement, with the aim of checking the extent to which our sample of parents is representative of the

Albanian adult population. With respect to social engagement, we collected information about: 1) membership in voluntary organizations; 2) participation in any community activity in the past year; 3 ) beliefs about community members' willingness to cooperate with each other in case of a water shortage; and 4) a measure of generalized trust. After the subjects participated in the public goods game, we also collected information about the existing social ties between the experimental participants. We therefore

\footnotetext{
${ }^{18}$ Participation in elections of various kinds is a repeated behavior and, this being the case, it would have been interesting to conduct a repeated public goods game. However, for logistical reasons, we chose to conduct a one shot game. The simplicity of the game ensured that it would be readily understood by participants of varying cognitive ability and could be conducted using only universally available technologies such as pens, paper and pin boards. This, in turn, reduced the likelihood of our field research team having to deviate from the original sample design for any reason.

${ }^{19}$ See the instructions in Appendix for a full description of the examples employed in both versions of the public goods experiment. As we discuss in the next section, the specific example used does not affect the correlation between individuals' behavior in the public goods game and their participation in accountability systems. For an example of a study finding evidence of framing effects in a public goods game conducted with salmon fishers and reindeer herders in Russia, see Gerkey (2013).

${ }^{20}$ The 2008 LSMS is the third household survey conducted by the Albanian National Statistics Office with the technical assistance of the World Bank. The LSMS sampling relies on a stratification scheme based on four regions: Coastal Area, Central Area, Mountain Area, and Tirana; and included 450 Primary Sampling Units (PSUs) and 8 households in each PSU, for a total of 3600 households. The sampling is designed to be representative of Albania as a whole. The survey provides information about household characteristics, including demographics, education, as well as measures of social engagement.
} 
Table 1

Individual Characteristics

\begin{tabular}{|c|c|c|c|c|c|}
\hline & \multicolumn{2}{|c|}{$\begin{array}{c}\text { School } \\
\text { Stakeholder } \\
\text { Survey }\end{array}$} & \multicolumn{2}{|c|}{2008 LSMS } & \multirow{2}{*}{$\begin{array}{l}\text { District-level } \\
\text { coefficient of } \\
\text { correlation }\end{array}$} \\
\hline & Mean & SD & Mean & SD & \\
\hline \multicolumn{6}{|l|}{ Demographics } \\
\hline Average years of education & 10.98 & 3.25 & 10.73 & 3.36 & 0.25 \\
\hline Average age & 40.17 & 6.39 & 44.22 & 17.58 & -0.27 \\
\hline Wealth indicator & 0.00 & 0.92 & n.a. & n.a. & \multirow{2}{*}{$0.52 * * *$} \\
\hline Household yearly income (in 000LEK) & n.a. & n.a. & 385 & 1,894 & \\
\hline \multicolumn{6}{|l|}{ Survey-based measures of social engagement } \\
\hline Belongs to an organization (church, political group, sport etc.) & 0.02 & 0.15 & 0.24 & 0.75 & -0.08 \\
\hline Participated in any community activity in the past year & 0.15 & 0.35 & 0.11 & 0.31 & -0.01 \\
\hline $\begin{array}{l}\text { Thinks village members would cooperate in the case of water } \\
\text { shortage }\end{array}$ & 0.72 & 0.45 & 0.64 & 0.48 & -0.15 \\
\hline Think that "most people can be trusted" & 0.13 & 0.34 & 0.27 & 0.17 & -0.02 \\
\hline$\%$ of relatives or friends among other parents & 0.06 & 0.90 & n.a. & n.a. & \\
\hline \multicolumn{6}{|l|}{ Involvement with the pupil's education: } \\
\hline Help with homework at least once a week & 0.76 & 0.43 & 0.54 & 0.50 & 0.06 \\
\hline $\begin{array}{l}\text { Number of meetings with head teacher in the previous } \\
\text { semester }\end{array}$ & 4.52 & 3.3 & n.a. & n.a. & \multirow{2}{*}{$0.34 * *$} \\
\hline Number of visits to the child's school in the previous year & n.a. & n.a. & 8.73 & 3.39 & \\
\hline \multicolumn{6}{|l|}{ Information about participatory accountability institutions: } \\
\hline Knows about the existence of parent class representatives & 0.72 & 0.45 & n.a. & n.a. & \multirow[b]{3}{*}{$0.32 *$} \\
\hline Knows about the existence of the school board & 0.58 & 0.49 & n.a. & n.a. & \\
\hline $\begin{array}{l}\text { Knows about the existence of participatory accountability } \\
\text { institutions at the school level }\end{array}$ & n.a. & n.a. & 0.68 & 0.47 & \\
\hline $\begin{array}{l}\text { Participation in the last elections of parent class } \\
\text { representatives }\end{array}$ & 0.50 & 0.50 & n.a. & n.a. & \\
\hline
\end{tabular}

Note: $* * * \mathrm{p}<0.01, * * \mathrm{p}<0.05, * \mathrm{p}<0.1$

have a number of survey measures of individuals' involvement in the community, which might also be interpreted as proxies for individual-level and/or community-level social capital. ${ }^{21}$ However, given the measurement problems that characterize these proxies, we devote minimal attention to their analysis and interpretation. ${ }^{22}$ We nevertheless incorporate them in our empirical analysis as control variables to test the robustness of our main findings. While we consider our experimental proxy to be a superior measure

\footnotetext{
${ }^{21}$ There are many definitions and conceptualizations of social capital. Some researchers use the term social capital to refer to the structure of communities, i.e. the presence of network structures defining "bonding" and/or "bridging" links among community members (e.g., Putnam, 2000), while others use it to refer to individual attitudes and preferences such as propensities to trust and cooperate with others (e.g., Fukuyama, 1995; Bowles and Gintis, 2002). Carpenter (2002) aimed to reconcile these two strands of the literature by referring to the former conceptualization as associational social capital and the latter as behavioral social capital. Our experimental measure of individuals' willingness to cooperate with others could be viewed as a measure of behavioral social capital.

${ }^{22}$ For assessments of attitudinal survey measures based on a comparison with the corresponding experimental measures, see Ahn et al. (2003), Ashraf et al. (2003), Gaechter et al. (2004) and Glaeser et al. (2000). For a discussion and comparison of the survey based and the experimental based measures of social capital, see Carpenter (2002).
} 
of the behavioral tendency we are interested in capturing, we see the survey measures as potentially important controls capturing unobservable factors such us heterogeneous local institutional environments and differential opportunities for cooperation outside the school environment.

Table 1 summarizes the characteristics of the 1800 parents randomly selected to participate in the 2009 School Stakeholder Survey and the characteristics of the adult Albanian population selected to participate in the 2008 Albanian Living Standards Measurement Survey. ${ }^{23}$ For each variable we aggregated the data at the district level and computed district-level correlations between the two samples. We also tested for equality of district-level means.

The most apparent demographic characteristic that differentiates our subjects from the LSMS subjects is the fact that they are all parents of elementary school kids. As a consequence, there are significant differences in the age distributions of the two populations. While the average ages are strikingly similar across the two samples, the minimum age in our sample is 29 as opposed to 18 in the LSMS adult sample and the maximum age in our sample is 60 as opposed to 101 in the LSMS sample. Moreover 20 per cent of the LSMS respondents are older than 60. When aggregating the data at the district level, we find that average age is significantly higher in the LSMS sample. We find no district-level correlation between the average age of our subjects and the LSMS subjects. There is also no significant correlation between our survey measures of trust, memberships in organizations, participation in community activities and beliefs about villagers' cooperation attitudes. With the exception of participation in community activities, the means of the social engagement variables are significantly different across the two samples. On the other hand, there are significant district-level correlations between the income variable elicited in the LSMS survey and our wealth index, which we constructed following Filmer and Pritchett (2001), i.e. by conducting principal factor analysis on the subjects' answers to 14 questions about ownership of consumer durables, such as washing machines, refrigerators, ovens, cars, and mobile phones. ${ }^{24}$ Table 1 reports the resulting first factor, which we refer to as a household wealth indicator. We also find significant district-level correlations between our survey variables and the LSMS variables that refer directly to individuals' involvement in their children's education and their information about participatory institutions at the school level. ${ }^{25}$ The statistics obtained for these variables in the two samples are also

\footnotetext{
${ }^{23}$ Table A1 in Appendix reports the specific questions used in the two surveys to generate measures of social engagement and of parental involvement with their children's education.

${ }^{24}$ Principal factor analysis is a technique used to summarize information contained in a large number of correlated variables into a smaller number of mutually uncorrelated components. The first factor or component is the linear index of all the observed variables that captures the most common variation among them. The first factor or component in our analysis captures $53 \%$ of the common variation among the 14 asset variables. We do not have income data from our survey. The district-level coefficient of correlation between our asset variable and the income variable collected by the LSMS, equal to 0.52 and significant at the 1 per cent level, suggests that our proxy does a good job in capturing wealth differences across our survey participants.

${ }^{25}$ The coefficient of correlation between average number of meetings with the head teacher in our survey and number of visits to the school in the LSMS is equal to 0.34 and significant at the 5 per cent level. The coefficient of correlation between the percentage of informed parents in our survey and in the LSMS is equal to 0.32 and significant at the 10 per cent level.
} 
very similar. For instance, $72 \%$ of our surveyed parents are informed about the existence of parent class representatives in our survey, and $68 \%$ of the LSMS respondents are informed about the existence of parent-teacher associations or "other means for parents to be involved in school activities". ${ }^{26}$

To summarize, we found significant district-level correlations between our wealth index and the income variable elicited in the LSMS survey, as well as the variables that refer directly to individuals' involvement in their children's education and their information about participatory institutions at the school level. However, we found no significant correlation between the LSMS and our survey measures of trust, memberships in organizations, participation in community activities and beliefs about villagers' cooperation attitudes. The latter may be due to the significant difference in age distribution between the LSMS and our sample. Overall, the comparisons displayed in Table 1 suggest that our sample is representative of Albanian adults that are parents of elementary school children.

The last row of Table 1 shows that $50 \%$ of the surveyed parents participated in the last elections of parent class representatives. Parental participation varies significantly across counties, ranging from 33\% in the Shkoder county to $63 \%$ in the Vlore county. Further disaggregation to the district level shows an even greater variation in the proportion of participating parents, ranging from $18 \%$ in the Shkoder district to $95 \%$ in the Delvine district (See Table A2 in Appendix). Chi-squared tests show that the county-level and district-level differences in participation are significant at the 1 per cent level. Participation is also highly variable across schools, ranging from no participating parents (among the surveyed ones), observed in 5 per cent of the schools, to full participation, observed in 3 per cent of the schools. Due to the observational nature of our data, we are unable to establish whether there is a causal link from parental participation to better school outcomes. However, simple correlations show that in schools with higher levels of parental participation more students excel in Math and Albanian in the eighth grade centrally administered leaving examination, fewer students fail such exams and fewer students repeat a year. Moreover schools with more participating parents seem to be characterized by significantly higher parental satisfaction and lower (perceived) corruption in the form of embezzlement of school resources (see Table A2 in Appendix).

\subsection{Cooperative behavior in the public goods experiment}

In the public goods game, $75 \%$, of the parents invested in the group account rather than the private account. There are only three public goods experiments that are comparable to ours. Cardenas et al. (2013) found that the percentage of contributors to the group account in 6 Latin American capitals ranged between $12 \%$ in Bogota' and $47 \%$ in Caracas. In two different neighborhoods in Colombia, Attanasio et

\footnotetext{
${ }^{26}$ At the district level, the differences between the averages of the variables measuring parents' involvement with their children's education and information about accountability systems are statistically significant.
} 
al. (2009) found that $7 \%$ and $33 \%$ of the participants invested in the group account. ${ }^{27}$ However, the public goods games used in both of these studies involved much smaller MPCRs, 0.10 in Cardenas et al. and 0.08 in Attanasio et al., and require a larger number of contributors to the group account in order for each contributor to earn at least as much as he/she would earn by investing in the private account, 10 in Cardenas et al. and 13 in Attanasio et al. Therefore, by design, our experiment was likely to generate a higher rate of contribution to the group account among other regarding subjects. ${ }^{28}$ Barr et al. (2013) conducted a dichotomous public goods game in Uganda employing the same payoff structure as in our game, hence the same MPCR of 0.20 , but involving groups of 12 rather than 15 individuals. The percentage of individuals contributing to the public good in Uganda ranged from 50 to 70 per cent across treatments and subject types - the game involved teacher representatives, head teachers, parent representatives and management representatives. ${ }^{29}$

We see significant differences in cooperation across counties, ranging from $61 \%$ in Fier to $88 \%$ in Gjirokaster. A Chi-squared test shows that the between-county differences are statistically significant at the 1 per cent level. At the district level, the variation in the percentage of cooperating parents is even more striking, ranging from $47 \%$ in the district of Lushnje to $95 \%$ in the district of Delvine (see Table A3 in Appendix). The differences in cooperating behavior across districts are statistically significant at the 1 per cent level. A linear probability model employing only the district dummies as explanatory variables shows that the 36 districts account for 6 per cent of the variation in individual cooperativeness in the game, and for 25 per cent of the variation in cooperativeness across schools. ${ }^{30}$

One community characteristic that has been shown to affect individual contributions to public goods (Habyarimana et al. 2007) and participation in community activities (Alesina and La Ferrara, 2000) is ethnic fragmentation. Comparing cooperation in the four main geographical areas of Tirana, the Coast, the Centre and the Mountain shows that parental cooperation in the game is significantly lower in the coastal area. This may be owing to the recent flow of migrants from the Mountains to the Coast and the consequently growing linguistic and cultural fragmentation in that region. Finally, while Albania is a

\footnotetext{
${ }^{27}$ The authors relate these different percentages to the fact that in the previous two years the latter neighbourhood had been involved in a conditional cash transfer scheme that had a community engagement component.

${ }^{28}$ In choosing the parameters for our game, we were guided by the particular characteristics and historical background of Albania. Expecting Albanians to be relatively uncooperative, we parameterised the game so that cooperation among participants would be more attractive than in previous parameterisations.

${ }^{29}$ Henrich et al. (2005) show that, in standard public goods games conducted in 5 small-scale societies, the percentage of "freeriders", i.e. participants who contributed nothing into a public account, ranged from 0 to $5 \%$; however the public good games employed had a much higher MPCR (0.40 or 0.50) and smaller groups (4 or 5 people). Cardenas and Carpenter (2008) review studies employing public goods experiments in the field, and report that average contribution range from $33 \%$ of endowment in Chile (Henrich and Smith , 2004) to $81 \%$ in Peru (Karlan, 2005).

${ }^{30}$ The public good game was played also by 5 teachers. The behavior of teachers is remarkably similar to that of parents, with $76 \%$ of teachers investing in the group account, and variations among counties and districts being highly statistically significant. Moreover, there is a strong positive correlation between the behavior of teachers and the behavior of parents in the public goods game at the district level. The coefficient of correlation is 0.44 and is significant at the $1 \%$ level. This suggests that cooperative tendencies are shared by different actor-types embedded in the same communities. Given the focus of the paper on participatory accountability, here we focus only on the behavior of parents.
} 
prevalently Muslim country, a significant number of followers of other religions (Orthodox and Catholic Christianity) exist. ${ }^{31}$ Based on the LSMS data, we constructed a district-level proxy for religious homogeneity, i.e., a dummy equal to 1 if in the district there exists a religion whose followers constitute more than 90 per cent of the population, and 0 otherwise. About 40 per cent of the districts are religiously homogeneous, and the percentage of cooperating parents in these districts is 78 per cent, against 73 per cent in more heterogeneous districts; the difference is significant at the 5 per cent level.

Table 2

Determinants of cooperativeness in the public good game

\begin{tabular}{|c|c|c|c|c|c|}
\hline & \multicolumn{5}{|c|}{$\begin{array}{c}\text { Dependent variable: } \\
\text { Dummy equal to } 1 \text { if parent invested in the group account, } \\
0 \text { otherwise }\end{array}$} \\
\hline & $\begin{array}{c}\text { Probit } \\
\text { (1) }\end{array}$ & $\begin{array}{c}\text { Probit } \\
\text { (2) }\end{array}$ & $\begin{array}{c}\text { Probit } \\
\text { (3) }\end{array}$ & $\begin{array}{c}\text { Probit } \\
\text { (4) }\end{array}$ & $\begin{array}{c}\text { Probit } \\
\text { (5) }\end{array}$ \\
\hline \multirow[t]{2}{*}{ Age } & $-2 \mathrm{E}-04$ & $-5 \mathrm{E}-04$ & $-4 \mathrm{E}-04$ & $-4 \mathrm{E}-04$ & $-7 \mathrm{E}-04$ \\
\hline & $(0.927)$ & $(0.802)$ & $(0.808)$ & $(0.806)$ & $(0.688)$ \\
\hline \multirow[t]{2}{*}{ Female } & -0.012 & -0.010 & -0.003 & -0.000 & -0.003 \\
\hline & $(0.584)$ & $(0.656)$ & $(0.883)$ & $(0.989)$ & $(0.878)$ \\
\hline \multirow[t]{2}{*}{ Wealth index } & 0.019 & 0.022 & $0.028 *$ & $0.031 * *$ & 0.023 \\
\hline & $(0.219)$ & $(0.151)$ & $(0.052)$ & $(0.036)$ & $(0.109)$ \\
\hline \multirow[t]{2}{*}{ Years of schooling } & 0.003 & 0.004 & 0.003 & 0.004 & 0.002 \\
\hline & $(0.375)$ & $(0.304)$ & $(0.355)$ & $(0.322)$ & $(0.562)$ \\
\hline \multirow[t]{2}{*}{ Member of a social organization } & & -0.040 & -0.046 & -0.048 & -0.035 \\
\hline & & $(0.610)$ & $(0.564)$ & $(0.549)$ & $(0.646)$ \\
\hline \multirow[t]{2}{*}{ Participated in community activities } & & -0.032 & -0.034 & -0.034 & -0.037 \\
\hline & & $(0.300)$ & $(0.274)$ & $(0.278)$ & $(0.251)$ \\
\hline \multirow[t]{2}{*}{ Generalized trust } & & 0.021 & 0.020 & 0.024 & -0.002 \\
\hline & & $(0.547)$ & $(0.564)$ & $(0.482)$ & $(0.957)$ \\
\hline \multirow[t]{2}{*}{ Thinks village members would work together } & & -0.007 & -0.009 & -0.011 & -0.006 \\
\hline & & $(0.750)$ & $(0.708)$ & $(0.629)$ & $(0.771)$ \\
\hline \multirow[t]{2}{*}{ N. of good friends among parents } & & 0.007 & 0.004 & 0.001 & -0.003 \\
\hline & & $(0.508)$ & $(0.678)$ & $(0.882)$ & $(0.727)$ \\
\hline \multirow[t]{2}{*}{ N. of relatives among parents } & & $0.062 * *$ & $0.060 * *$ & $0.053 * *$ & 0.047 \\
\hline & & $(0.026)$ & $(0.030)$ & $(0.047)$ & $(0.101)$ \\
\hline \multirow[t]{2}{*}{ Rural area } & & & -0.029 & -0.018 & -0.021 \\
\hline & & & $(0.411)$ & $(0.611)$ & $(0.537)$ \\
\hline \multirow[t]{2}{*}{ Standard deviation of wealth (school-level) } & & & -0.096 & -0.079 & -0.075 \\
\hline & & & $(0.121)$ & $(0.204)$ & $(0.213)$ \\
\hline \multirow[t]{2}{*}{ Religious homogeneity (district-level) } & & & $0.055^{*}$ & $0.062 *$ & \\
\hline & & & $(0.077)$ & $(0.081)$ & \\
\hline \multirow[t]{2}{*}{ Coastal area } & & & & $-0.085^{* *}$ & \\
\hline & & & & $(0.028)$ & \\
\hline \multirow[t]{2}{*}{ Tirana area } & & & & -0.002 & \\
\hline & & & & $(0.969)$ & \\
\hline \multirow[t]{2}{*}{ Mountain area } & & & & -0.044 & \\
\hline & & & & $(0.338)$ & \\
\hline District fixed effects & No & No & No & No & Yes \\
\hline Joint significance of geographical areas ( $p$-value) & - & - & - & 0.142 & - \\
\hline Joint significance of district f.e.(p-value) & - & - & - & - & $<0.001$ \\
\hline Observations & 1,800 & 1,800 & 1,800 & 1,800 & 1,800 \\
\hline
\end{tabular}

${ }^{31}$ In three districts the majority of the population is Catholic, and in one district the majority is Orthodox. 
In Table 2, we conduct probit regressions where the dependent variable is the individual decision to invest in the group rather than the private account in the game. We report marginal effects evaluated at the means for continuous explanatory variables and the effect of a change from 0 to 1 for dichotomous explanatory variables. In column 1 we control for demographics, and in column 2 we add individual measures of social engagement and involvement with children's education. Given the significant differences in behavior across districts, in column 3 we add community characteristics generated by the school survey and the LSMS and in column 4 we add dummies for the Coastal, the Mountain, the Central and Tirana geographical areas. Finally, in column 5 we add district fixed effects.

Two of the five models suggest that wealthier individuals are more likely to invest in the group account, whereas no significant differences based on age, gender and education exist. Among the social engagement measures, the number of relatives in the session increases cooperation in the game in three of the five models. This is not surprising, as the number of relatives among other participants is likely to affect one's beliefs about others' willingness to cooperate. On the other hand, the fact that the presence of "friends" in the session does not have a similar effect provides suggestive evidence that Albania is a close-knit, family oriented society. Table 2 columns 3 and 4 indicate that religious homogeneity significantly increases parents' cooperativeness in the game. Moreover, parents seem to behave less cooperatively in the more culturally and linguistically heterogeneous coastal region. Finally, we note that none of the significant variables are robust to the inclusion of district fixed effects, confirming that much of the variation in individual willingness to cooperate with others for the common good occurs at the community level.

\section{Results}

In this section, we first present results from individual-level regression analysis concerning the relationship between individuals' cooperativeness and the short and the long routes to accountability, and then turn to district-level analysis.

\subsection{Individual-level analysis}

\subsubsection{The short route to accountability}

We estimate individual-level Probit models where the dependent variable is a dummy equal to 1 if the parent participated in the latest elections of parent class representatives, and zero otherwise. Table 3 reports marginal effects evaluated at the mean for continuous explanatory variables and the effect of a change from 0 to 1 for dichotomous explanatory variables. In all regressions we cluster the standard errors at the school level. In the first model, we control for the four geographical areas identifying 
Table 3

\section{Cooperativeness and the short route to accountability (individual-level)}

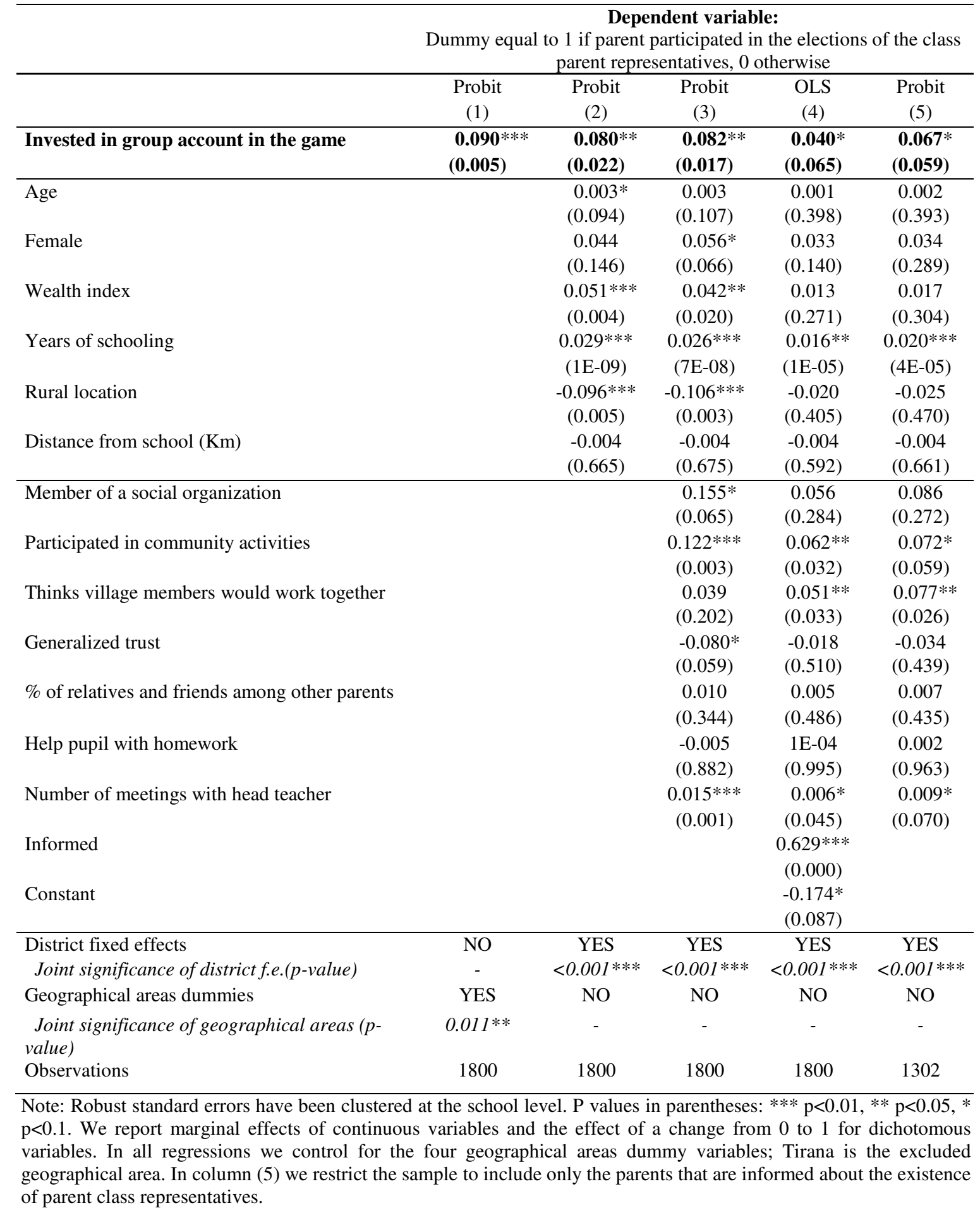


different economic realities within the Albanian territory. In the other four models we introduce district fixed effects. The district fixed effects are particularly important given the significant differences in behavior in the public goods game across districts identified in the previous section. ${ }^{32}$

In column 1 of Table 3 we do not include any controls beside the geographical area dummies. In column 2 we control for standard demographics, ${ }^{33}$ the urban or rural location of the surveyed school, the distance of the parent's house from the school, and district fixed effects. In column 3 we add surveybased measures of social engagement and of parents' involvement with their children's education.

The estimates in all columns show a strong and robust correlation between parents' decisions to invest in the group account in the public goods game and their participation in the elections of parent class representatives. $^{34}$

One important factor, which we left out from the specifications in columns 1 to 3 is the extent to which parents are informed about the elections of parent class representatives. From the survey, we know whether parents are aware of the existence of both parent class representatives and school boards. Since being unaware of the existence of parent class representatives precludes participation in their election, we cannot control for this variable in our Probit models. We address this problem in two ways. First, in column 4 we estimate a linear probability model including parents' information about parent class representatives as an additional explanatory variable. Second, in column 5, we estimate a Probit model similar to that presented in column 3 , while restricting the sample to parents who are informed about the existence of parent class representatives.

Column 4 and 5 of Table 3 show that, while, as expected, information is a determining factor of parents' participation, parents' willingness to cooperate with others in the public goods experiment remains a predictor of participation in the election of parent class representatives. Our result is also robust to restricting the sample to the informed parents and estimating a Probit model. The estimated coefficient becomes smaller as compared to column 3, but it retains statistical significance at the $10 \%$ level, with a pvalue of $0.057 .{ }^{35}$ The smaller and less significant coefficient within the informed sample, suggests that those who invested in the group account were also more likely to select into the informed sub-sample. A simple econometric analysis confirms that those who invested in the group account were also more likely

\footnotetext{
${ }^{32}$ Owing to the limited number of observation in each session/school and the limited variation within schools, including school fixed effects would dramatically reduce our ability to identify any relationships. However, if we aggregate the data at the school level and rerun our analyses, the results are robust, i.e. we find that schools in which more parents are cooperative in the VCM game are characterized by higher parental participation in school elections.

${ }^{33}$ While we do not have any prior about the relationship between participation and parents' age and gender, we expect wealthier and better educated parents to place a higher value on their children's education and face lower marginal costs of participation.

${ }^{34}$ In our sample, $28 \%$ of the parents were or had previously been a parent class representative. If we include a parent representative dummy among the explanatory variables, we find that, as expected, (current or past) parent class representatives are significantly more likely to participate in the school election. On the other hand, current or past parent class representatives are not more or less likely to invest in the group account. The estimates are available from the authors upon request.

${ }^{35}$ Table A4 in Appendix shows that the frame used in the example employed to explain the public goods game does not affect the predictive power of the behaviour in the game.
} 
to select into the informed sub-sample. ${ }^{36}$ These results provide suggestive evidence that acquiring information is effectively the first step toward participating.

Table 4

Cooperativeness and the long-route to accountability (self-reported)

\begin{tabular}{|c|c|c|c|}
\hline & \multicolumn{3}{|c|}{$\begin{array}{c}\text { Dependent variable: } \\
\text { Dummy equal to } 1 \text { if parent participated in the } \\
2009 \text { national elections, } 0 \text { otherwise }\end{array}$} \\
\hline & $\begin{array}{c}\text { Probit } \\
\text { (1) }\end{array}$ & $\begin{array}{l}\text { Probit } \\
\text { (2) }\end{array}$ & $\begin{array}{l}\text { Probit } \\
\text { (3) }\end{array}$ \\
\hline Invested in group account in the game & $\begin{array}{c}\mathbf{0 . 0 4 5}^{*} * * \\
(0.001)\end{array}$ & $\begin{array}{c}0.042 * * * \\
(0.001)\end{array}$ & $\begin{array}{c}0.042 * * * \\
(3 E-04)\end{array}$ \\
\hline Age & & $\begin{array}{c}0.004 * * * \\
(3 \mathrm{E}-05)\end{array}$ & $\begin{array}{c}0.004 * * * \\
(2 \mathrm{E}-05)\end{array}$ \\
\hline Female & & $\begin{array}{c}0.009 \\
(0.434)\end{array}$ & $\begin{array}{c}0.011 \\
(0.280)\end{array}$ \\
\hline Wealth index & & $\begin{array}{c}0.017 * * \\
(0.024)\end{array}$ & $\begin{array}{c}0.015 * * \\
(0.031)\end{array}$ \\
\hline Years of schooling & & $\begin{array}{c}0.003 \\
(0.135)\end{array}$ & $\begin{array}{c}0.002 \\
(0.307)\end{array}$ \\
\hline Rural location & & $\begin{array}{c}0.014 \\
(0.283)\end{array}$ & $\begin{array}{c}0.014 \\
(0.259)\end{array}$ \\
\hline Distance from school (Km) & & $\begin{array}{c}-0.004 \\
(0.275)\end{array}$ & $\begin{array}{c}-0.003 \\
(0.286)\end{array}$ \\
\hline Participated in community activities & & & $\begin{array}{c}0.017 \\
(0.243)\end{array}$ \\
\hline Thinks village members would work together & & & $\begin{array}{l}0.022 * \\
(0.055)\end{array}$ \\
\hline Generalized trust & & & $\begin{array}{l}-0.027 * \\
(0.074)\end{array}$ \\
\hline$\%$ of relatives and friends among other parents & & & $\begin{array}{c}0.005 \\
(0.175) \\
\end{array}$ \\
\hline Help pupil with homework & & & $\begin{array}{c}0.019 \\
(0.119)\end{array}$ \\
\hline Number of meetings with head teacher & & & $\begin{array}{c}0.002 \\
(0.154)\end{array}$ \\
\hline District fixed effects & NO & $\mathrm{NO}$ & NO \\
\hline Joint significance of district f.e. (p-value) & - & - & - \\
\hline Geographical areas dummies & YES & YES & YES \\
\hline Joint significance of geographical areas dummies (p-value) & 0.831 & 0.434 & 0.498 \\
\hline County fixed effects & NO & YES & YES \\
\hline Joint significance of county f.e. (p-value) & - & $<0.001 * * *$ & $<0.001 * * *$ \\
\hline Observations & 1800 & 1800 & 1800 \\
\hline
\end{tabular}

${ }^{36}$ Results are available from the authors. 


\subsubsection{The long route to accountability}

In this subsection, we turn our attention to the long route to accountability and citizens' willingness to hold public officials accountable through the instrument of the vote in parliamentary elections. We investigate whether parents who invested in the group account in the public goods game are more likely to have voted. We asked parents whether they voted in the most recent (2009) parliamentary election and we also collected data on district-level voter turnout from official records. According to our School Stakeholder Survey, 93\% of the parents voted in the 2009 parliamentary elections, whereas official records show that turnout was only $51 \%$. Given this discrepancy, we make use of the data from both sources; we investigate whether parents' behavior in the game correlates with turning out to vote both at the individual level using self-reported turnout and at the district level and, then repeat the district-level analysis using official turnout figures. The district level analysis is reported in Section 5.2.

In Table 4, we report estimated coefficients from individual-level Probit estimations where the dependent variable is a dummy equal to one if the parent stated that he/she voted in the 2009 parliamentary elections and zero otherwise. We employ the specifications used when analyzing the short route to accountability, in Table 3. The only differences is that, owing to limited within-district variation in self-reported turn-out, we are unable to employ district fixed effects without losing a substantial number of observations. This is why in columns 2 and 3 of Table 4 we employ county fixed effects instead. We acknowledge that our set of controls is likely to be missing important explanatory variables, such as the extent of individual information about the parliamentary elections and the candidates, as well as the degree of exposure to electoral campaigns. The county fixed effects allow us to at least partially address geographical differences in information, campaigns and political alliances.

Our experimental measure of cooperativeness is highly statistically significant and this is robust to changes in the empirical specification. The estimates indicate that parents who invested in the group account in the game are about $4 \%$ more likely to have voted in the most recent parliamentary elections. ${ }^{37}$

\subsection{District-level analysis}

In this section we investigate whether both parental participation in school accountability and participation in the 2009 parliamentary elections are higher in districts characterized by a higher fraction of individuals willing to cooperate with each other in collective action situations.

\footnotetext{
${ }^{37}$ While, as previously stated, we are not interested in the estimated coefficients of the attitudinal survey measures, which we included only as controls, we note that most of these variables appear with the expected, albeit intermittently significant positive sign. One exception is the survey measure of interpersonal trust, the negative sign on which suggests that parents who think that "most people can be trusted" are less likely to participate in the school accountability system and to vote in national elections. A speculative explanation for this result may be that more "trusting parents" trust others to make the right voting decisions, and/or trust teachers and politicians to act in the public's best interest.
} 


\subsubsection{The short route to accountability}

We aggregate parents' decisions to invest in the group account in the public good game and parents' decision to participate in the election of parent class representatives at the district level, and investigate their correlation while controlling for district characteristics generated by the 2008 LSMS Albanian household survey. The sample size is therefore reduced to 36 observations (i.e. the number of Albanian districts).

Table 5

Cooperativeness and the short-route of accountability (district-level)

\begin{tabular}{|c|c|c|c|c|}
\hline & \multicolumn{4}{|c|}{$\begin{array}{c}\text { Dependent Variable } \\
\text { District-level percentage of parents who participated in } \\
\text { the school accountability system in a district } \\
\text { (School Survey) }\end{array}$} \\
\hline & $\begin{array}{c}\text { OLS } \\
(1)\end{array}$ & $\begin{array}{c}\text { OLS } \\
\text { (2) }\end{array}$ & $\begin{array}{c}\text { OLS } \\
\text { (3) }\end{array}$ & $\begin{array}{c}\text { OLS } \\
\text { (4) }\end{array}$ \\
\hline$\%$ parents investing in the group account in the district & $\begin{array}{l}0.565^{*} \\
(0.056)\end{array}$ & $\begin{array}{l}0.581 * \\
(0.074)\end{array}$ & $\begin{array}{l}\mathbf{0 . 7 5 3}^{*} \\
(\mathbf{0 . 0 3 3 )}\end{array}$ & $\begin{array}{l}0.676 * \\
(0.089)\end{array}$ \\
\hline ln of household income & & $\begin{array}{c}-0.007 \\
(0.897)\end{array}$ & $\begin{array}{c}-0.018 \\
(0.756)\end{array}$ & $\begin{array}{l}-0.155 \\
(0.364)\end{array}$ \\
\hline Average years of schooling of the adult population & & $\begin{array}{l}-0.006 \\
(0.874)\end{array}$ & $\begin{array}{c}-0.019 \\
(0.639)\end{array}$ & $\begin{array}{l}-0.015 \\
(0.734)\end{array}$ \\
\hline$\%$ people who belong to a social organization & & & $\begin{array}{l}-0.017 \\
(0.925)\end{array}$ & $\begin{array}{c}0.030 \\
(0.884)\end{array}$ \\
\hline$\%$ people who participate in community activities & & & $\begin{array}{c}0.134 \\
(0.484)\end{array}$ & $\begin{array}{c}0.022 \\
(0.927)\end{array}$ \\
\hline Average perception of village members' willingness to work together & & & $\begin{array}{c}-0.143 * * \\
(0.030)\end{array}$ & $\begin{array}{c}-0.147 * * \\
(0.041)\end{array}$ \\
\hline$\%$ of people "trusting others" & & & $\begin{array}{c}0.060 \\
(0.760)\end{array}$ & $\begin{array}{c}0.157 \\
(0.498)\end{array}$ \\
\hline Standard Deviation of household income & & & & $\begin{array}{c}2 \mathrm{E}-08 \\
(0.673)\end{array}$ \\
\hline Prevalently Muslim & & & & $\begin{array}{l}-0.031 \\
(0.720)\end{array}$ \\
\hline Religious homogeneity & & & & $\begin{array}{c}0.031 \\
(0.720)\end{array}$ \\
\hline Northern region & & & & $\begin{array}{c}0.043 \\
(0.785)\end{array}$ \\
\hline Constant & $\begin{array}{c}0.381 \\
(0.228) \\
\end{array}$ & $\begin{array}{c}0.538 \\
(0.502) \\
\end{array}$ & $\begin{array}{c}1.071 \\
(0.179) \\
\end{array}$ & $\begin{array}{r}2.965 \\
(0.186) \\
\end{array}$ \\
\hline $\begin{array}{l}\text { County fixed effects } \\
\text { Joint significance of county f.e. }(p \text {-value) }\end{array}$ & $\begin{array}{l}\text { YES } \\
0.181\end{array}$ & $\begin{array}{l}\text { YES } \\
0.304\end{array}$ & $\begin{array}{l}\text { YES } \\
0.312\end{array}$ & $\begin{array}{l}\text { YES } \\
0.374\end{array}$ \\
\hline Geographical areas dummies & YES & YES & YES & YES \\
\hline Joint significance of geographical areas (p-value) & 0.112 & 0.164 & 0.049 & 0.080 \\
\hline Observations & 36 & 36 & 36 & 36 \\
\hline
\end{tabular}

Table 5 reports estimates from OLS regressions where the dependent variable is the proportion of parents who participated in the school accountability system in a district, and the explanatory variable of interest is the proportion of parents who behaved cooperatively in the game. We control for the average income and average years of schooling in the district (column 2), district-level measures of social engagement (column 3), and other district characteristics (column 4) discussed in previous section, i.e. 
religious homogeneity, a northern region dummy, four geographical area dummies, whether or not the district is prevalently Muslim, and the standard deviation of income within the district. In all regressions we employ county fixed effects. Table 5 indicates that more "cooperative" districts are characterized by a higher parental participation in the school accountability system.

\subsubsection{The long route to accountability}

In Table 6 we employ district-level official records of turnout in the 2009 parliamentary elections as our dependent variable. We use the same empirical specifications as in Table 5.

Table 6

\section{Cooperativeness and the long-route of accountability (official records)}

\begin{tabular}{|c|c|c|c|c|}
\hline & \multicolumn{4}{|c|}{$\begin{array}{c}\text { Dependent Variable } \\
\text { District-level percentage of citizens who voted in the } \\
2009 \text { parliamentary elections (official records) }\end{array}$} \\
\hline & $\begin{array}{c}\text { OLS } \\
(1)\end{array}$ & $\begin{array}{l}\text { OLS } \\
(2)\end{array}$ & $\begin{array}{l}\text { OLS } \\
\text { (3) }\end{array}$ & $\begin{array}{c}\text { OLS } \\
(4)\end{array}$ \\
\hline$\%$ parents investing in the group account in the district & $\begin{array}{c}0.114 \\
(0.133) \\
\end{array}$ & $\begin{array}{c}0.162 * * \\
(0.033) \\
\end{array}$ & $\begin{array}{c}\mathbf{0 . 1 6 0} * * \\
(\mathbf{0 . 0 3 3 )} \\
\end{array}$ & $\begin{array}{c}0.166 * * \\
(0.016) \\
\end{array}$ \\
\hline ln of household income & & $\begin{array}{c}-0.029 * * \\
(0.033)\end{array}$ & $\begin{array}{c}-0.038 * * * \\
(0.007)\end{array}$ & $\begin{array}{l}-0.017 \\
(0.533)\end{array}$ \\
\hline Average years of schooling of the adult population & & $\begin{array}{l}-0.001 \\
(0.882)\end{array}$ & $\begin{array}{c}0.004 \\
(0.619)\end{array}$ & $\begin{array}{c}0.003 \\
(0.663)\end{array}$ \\
\hline$\%$ people who belong to a social organization & & & $\begin{array}{c}0.082 * * \\
(0.046)\end{array}$ & $\begin{array}{l}0.062^{*} \\
(0.082)\end{array}$ \\
\hline$\%$ people who participate in community activities & & & $\begin{array}{c}0.040 \\
(0.324)\end{array}$ & $\begin{array}{l}-0.003 \\
(0.933)\end{array}$ \\
\hline Average perception of village members' willingness to work togethe & & & $\begin{array}{r}-0.023^{*} \\
(0.090)\end{array}$ & $\begin{array}{c}-0.027 * * \\
(0.024)\end{array}$ \\
\hline$\%$ of people "trusting others" & & & $\begin{array}{c}0.012 \\
(0.766)\end{array}$ & $\begin{array}{c}0.024 \\
(0.517)\end{array}$ \\
\hline Standard Deviation of household income & & & & $\begin{array}{l}-5 E-10 \\
(0.857)\end{array}$ \\
\hline Prevalently Muslim & & & & $\begin{array}{l}-0.024 \\
(0.177)\end{array}$ \\
\hline Religious homogeneity & & & & $\begin{array}{c}0.040 * * \\
(0.014)\end{array}$ \\
\hline Northern region & & & & $\begin{array}{c}0.063 * * \\
(0.027)\end{array}$ \\
\hline Constant & $\begin{array}{c}0.468 * * * \\
(0.080)\end{array}$ & $\begin{array}{c}0.826 * * * \\
(2 \mathrm{E}-04)\end{array}$ & $\begin{array}{c}0.904 * * * \\
(6 \mathrm{E}-05)\end{array}$ & $\begin{array}{c}0.761 * * \\
(0.046) \\
\end{array}$ \\
\hline $\begin{array}{l}\text { County fixed effects } \\
\text { Joint significance of county f.e. (p-value) }\end{array}$ & $\begin{array}{c}\text { YES } \\
<0.001\end{array}$ & $\begin{array}{l}\text { YES } \\
0.001\end{array}$ & $\begin{array}{l}\text { YES } \\
0.002\end{array}$ & $\begin{array}{l}\text { YES } \\
0.002\end{array}$ \\
\hline Geographical areas dummies & YES & YES & YES & YES \\
\hline Joint significance of geographical areas (p-value) & 0.030 & 0.012 & 0.005 & 0.001 \\
\hline Observations & 36 & 36 & 36 & 36 \\
\hline
\end{tabular}


The estimates show a highly significant correlation between district-level cooperativeness in the public goods game, and voter turnout in the parliamentary elections. The correlation is robust to the inclusion of the district-level controls generated by the 2008 LSMS survey. The estimated coefficient indicates that a one standard deviation increase in the proportion of cooperating parents in a district is associated, ceteris paribus, with a 2 percentage point increase in participation in the elections. Table 6 also indicates that turnout is higher in the northern region which, as previously discussed, is traditionally allied to the Democratic party that is in power since 2005. Consistent with the literature, the estimates also suggest that participation in parliamentary elections is higher in districts characterized by religious homogeneity.

Our analysis identifies a robust correlation between individuals' willingness to cooperate with others for the common good and participation in both school-level and national accountability systems and, thereby identifies a behavioral tendency that is important for participation in accountability systems. However, the nature of our data does not allow us to rule out the possibility of reverse causality. To partly mitigate the endogeneity concerns, we note that the election of parent representatives in schools was legislated for and expected to start at the same time in all the schools in the 2000s, so we can at least exclude that their institution or lack thereof is the result individuals' attitudes to cooperation for the common good. Moreover, our understanding is that the parents of each class are expected to meet at the beginning of the school year with the sole objective to elect their parent representative. All parent representatives subsequently meet to elect their own representative to the school board and to discuss school problems, including parents' concerns, with their school board representative. Therefore, at least on paper, the election meetings do not involve significant interactions among participants. Nevertheless, we cannot exclude the possibility that participation in these meetings increased participants' willingness to work together. Unfortunately, we cannot solve the endogeneity bias empirically through IV estimation because there are no variables in our data that can be considered exogenous to the behavior in the VCM game and that, at the same time, we can claim are not directly linked to participation. Finally, we note that the potential endogeneity problem does not apply to the same extent to participation in national elections. It is difficult to think of reasons why the act of voting in the national election would render an individual more willing to cooperate with others for the common good.

\section{Discussion and conclusions}

In this paper, we argued that the decision to participate in both school-level and national accountability systems can be characterized as collective action problems. Therefore, individuals' willingness to cooperate with others for the common good plays an important role in their decision to participate. This 
being the case, differences across societies in individuals' willingness and ability to overcome collective action problems might be one of the reasons why similar randomized interventions have generated different results when implemented in different countries.

We investigated whether both at the individual- and the community-level, willingness to cooperate with others for the common good is associated with willingness to participate both in local and national accountability systems, which we refer to as, respectively, a short and a long route to accountability. We conducted a nationally representative survey of 1800 randomly selected parents of children enrolled in primary schools in Albania. In order to isolate the effect of individuals' willingness to cooperate with others in collective action scenarios, we involved all the surveyed parents in a simple public goods game. At the individual-level, we tested whether parents who behaved cooperatively in the game were more likely to have participated in the most recent elections of parent class (i.e., the short route to accountability) and in the most recent parliamentary elections (i.e., the long route). At the communitylevel, we tested whether districts characterized by more cooperative parents have higher participation in school accountability and higher voter turnout, based on official records, while controlling for district characteristics generated by the most recent LSMS household survey.

Our empirical results show that cooperative parents are about 8 percent more likely to participate in the elections of parent class representatives and about 4 percent more likely to vote in national elections. This relationship remains significant after controlling for a range of variables including the degree to which parents are informed about the presence of local accountability institutions and district fixed effects. The district-level analysis indicates that districts characterized by a higher proportion of cooperative parents have a higher degree of participation in school accountability and a higher turnout in the 2009 elections, according to official records. In particular, a one standard deviation increase in the proportion of cooperating parents in a district is associated, ceteris paribus, with a 2 percentage point increase in voter turnout. While the sizes of the identified relationships might appear small, they are quite substantial when compared to the estimated effects of various randomized interventions on individuals' voting behavior. Green, Gerber, and Nickerson (2003) evaluated the effectiveness of a randomized intervention based on door-to-door canvassing before the November 6, 2001 US elections in six locations and found an average treatment effect of 7.1 percentage points. Gerber, Green and Larimer (2008) evaluated three randomized interventions aimed at increasing voter turnout in the 2006 primary elections in the state of Michigan. One intervention consisted in simply mailing a group of people a message reminding them that voting is a civic duty; one intervention consisted of telling voters that researchers would be studying their turnout based on public records and a final intervention consisted of telling people that the household voter turnout would be displayed to their neighbors. The Civic Duty intervention increase turnout by 1.8 percentage points; the "You Are Being Studied" intervention 
increased turnout by 2.5 percentage points, and the Neighbors Intervention increased turnout by 8.1 percentage points. The authors compared the marginal effects obtained from their treatments to those obtained by similar studies evaluating interventions attempting to increase voter turnout through messages and/or reminders sent to treated households by mail. They observed that "treatment effects in the 1.8 percentage point range, similar to the effects we observe for the Civic Duty mailing, are rare but not unprecedented, though one mail piece more commonly produces a result less than 1 percentage point. Results in the $5 \%$ to $8 \%$ range have never before been observed, even for a nine-piece mail program."

Our finding that both across individuals within districts and across districts willingness to cooperate is significantly associated with participation in short-route and long-route accountability systems could inform future research aimed at identifying ways to increase both local participation and civic engagement. Interventions attempting to improve collective action might be a viable and effective alternative (or addition) to interventions focusing purely on institutional changes or information campaigns. In the last three decades, experimental studies of cooperativeness in the public goods game have generated an extensive of body knowledge about why and when individuals are more likely to cooperate with others for the common good. Specifically, we know from lab experiments that (1) the majority of people are conditional cooperators, i.e., they cooperate if they think others will do likewise, and (2) that, this being the case, the dynamics of cooperation are driven by individual's expectations about what others will do. ${ }^{38}$ While identifying ways to promote collective action is beyond the scope of this paper, our findings together with findings from the existing experimental literature on public goods games suggest that efforts to improve individual citizens' perceptions about other citizens' willingness to participate in holding public servants to account might be an effective way to improve participation at both the local- and national-level.

\footnotetext{
${ }^{38}$ For a recent review of the public goods game literature, see Chaudhuri (2010)
} 


\section{ACKNOWLEDGMENTS}

We thank Klaus Abbink, Margaret McConnell, Ragan Petrie, John Ryan, Paula Cordero Salas, Tim Salmon, Sara Solnick, Pedro Vicente, Jane Zhang, three anonymous referees, and seminar participants at Florida State University, Southern Methodist University, the University of Texas Dallas, Wesleyan University, the 2011 SEA conference, and the 2011 North-American ESA meeting and the 2012 CSAE workshop in experimental development economics for useful comments and suggestions. We are indebted

to the Institute for Development Research Alternatives (IDRA), who collected the data, and especially Auron Pasha, Enkelejda Pashaj and Adela Gjergjani for their technical excellence and professionalism. The findings, interpretations and conclusions expressed herein are those of the authors and do not necessarily reflect the view of the World Bank Group, its Board of Directors or the governments they represent. The usual disclaimers apply.

\section{References}

Ahn, T.K., Ostrom, E., Schmidt, D.,Walker, J. (2003). "Trust in two-person games: game structures and linkages." In: Ostrom, E., Walker, J. (Eds.), Trust and Reciprocity. Interdisciplinary Lessons From Experimental Research. New York: Russell Sage Foundation, pp. 323-351.

Alesina, A. and E. La Ferrara (2000). "Participation in Heterogeneous Communities." The Quarterly Journal of Economics, 115(3): 847-904.

Ashraf, N., Bohnet, I., and N. Piankov (2006). "Decomposing trust and trustworthiness." Experimental Economics, 9(3): 193-208.

Attanasio O., L. Pellerano and S. Polanía Reyes (2009). "Building Trust? Conditional Cash Transfer Programmes and Social Capital." Fiscal Studies, 30(2): 139-177.

Banerjee, A., Rukmini B., Duflo, E., Glennerster, R. And S. Khemani (2010). "Pitfalls of Participatory Programs: Evidence from a Randomized Evaluation in Education in India." American Economic Journal: Economic Policy, 2 (1): 1-30.

Barr, A. and P. Serneels (2009). "Reciprocity in the Workplace." Experimental Economics, 12(1): 99-112.

Barr, A., Mugisha, F., Serneels, P. and A. Zeitlin (2012). "Information and collective action in community monitoring of schools: Field and lab experimental evidence from Uganda", working paper.

Bertrand, M. and S. Mullainathan (2001). "Do People Mean What They Say? Implications for Subjective Survey Data.” American Economic Review, 91(2): 67-72.

Blimpo, M., D. K. Evans and N. Lahire (2011). "School-Based Management and Educational Outcomes: Lessons from a Randomized Field Experiment.” Working paper, Stanford University.

Bowles, S., \& Gintis, H. (2002). "Homo reciprocans.” Nature, 415: 125-128. 
Bowles S. and H. Gintis (2002). "Social Capital and Community Governance." Economic Journal, 112(483): 419-436.

Bjorkman M. and J. Svensson (2010). "When is community-based monitoring effective? Evidence from a randomized experiment in primary health in Uganda." Journal of the European Economic Association, vol. 8 (2-3): 571-581.

Camerer C. (2014). "The promise and success of lab-field generalizability in experimental economics: A reply to Levitt and List (2007)," in G Frechette and A Schotter (Eds.), Methods in Experimental Economics, Oxford University Press.

Cárdenas J. C and C. R. Jaramillo (2007). "Cooperation In Large Networks: An Experimental." Documentos Cede 002202, Universidad De Los Andes.

Cardenas, J.C., A.Chong, H.Ñopo (2013) "Stated social behavior and revealed actions: Evidence from six Latin American countries". Journal of Development Economics 104 (2013) 16-33.

Cárdenas J. C. and J. Carpenter (2008). "Behavioral Development Economics: Lessons from field labs in the developing world." Journal of Development Studies, 44(3): 337-364.

Carpenter, J. (2002). "Measuring Social Capital: Adding Field Experimental Methods to the Analytical Toolbox in Social Capital, Economic Development and the Environment" In: Isham, J., Kelly, T., Ramaswamy, S. (Eds.), Social Capital and Economic Development: Well-Being in Developing Countries. Edward Elgar, Northampton, pp. 119-137.

Carpenter, J. and C. Myers (2010). "Why Volunteer? Evidence on the role of altruism, reputation and incentives." Journal of Public Economics, 94(11-12): 911-920.

Carpenter, J. and E. Seki (2011). "Do Social Preferences Increase Productivity? Field experimental evidence from fishermen in Toyama Bay." Economic Inquiry, 49(2): 612-630.

Casey, K., R. Glennerster, and E. Miguel (2012). "Reshaping Institutions: Evidence on Aid Impacts Using a Pre-Analysis Plan.” Quarterly Journal of Economics, 127(4): 1755-1812.

Chaudhuri, A. (2011). "Sustaining cooperation in laboratory public goods experiments: A selective survey of the literature." Experimental Economics, 14(1): 47-83.

Delavande A., Giné, X. and D. McKenzie (2011). "Measuring subjective expectations in developing countries: A critical review and new evidence." Journal of Development Economics 94: 151-163.

Doll, B. (2003). "The relationship between the clan system and other institutions in Northern Albania." Journal of Southeast European and Black Studies, 3 (2): 147-162.

Downs, A. (1957). An economic theory of democracy. New York: Harper and Row.

Duflo E, Dupas, P., and M. Kremer (2011). "Peer Effects and the Impact of Tracking: Evidence from a Randomized Evaluation in Kenya." American Economic Review, 101(5): 1739-74.

Fearon, J., Humphreys M. and J. M. Weinstein (2011). "Democratic Institutions and Collective Action Capacity: Results from a Field Experiment in Post-Conflict Liberia." Working paper, Stanford University. 
Fehr E. and A. Leibbrandt (2011). "A field study on cooperativeness and impatience in the Tragedy of the Commons.” Journal of Public Economics, 95 (9-10): 1144-1155.

Fehr, E., \& Gächter, S. (2000). "Cooperation and punishment in public goods experiments." American Economic Review, 90(4): 980-994.

Fischbacher, U., Gächter, S., \& Fehr, E. (2001). "Are people conditionally cooperative? Evidence from a public goods experiment.” Economics Letters, 71(3): 397-404.

Fischbacher, U., \& Gächter, S. (2010). "Social preferences, beliefs, and the dynamics of free riding in public good experiments.” American Economic Review, 100(1): 541-556.

Filmer D, Pritchett LH (2001). "Estimating wealth effect without expenditure data - or tears: an application to educational enrollments in states of India." Demography, 38:115-32.

Fukuyama, F. (1995). Trust: Social Virtues and the Creation of Prosperity. NY: Free Press.

Gächter S., Herrmann B., and C. Thöni (2004). "Trust, voluntary cooperation, and socio-economic background: survey and experimental evidence." Journal of Economic Behavior and Organization 55, 505-531.

Gächter, S., B. Herrmann and C. Thöni (2010). "Culture and Cooperation.” Philosophical Transactions of the Royal Society B - Biological Sciences, 365(1553): 2651-2661.

Gerber, A. S., D. P. Green and C. W. Larimer (2008). "Social pressure and voter turnout: Evidence from a large-scale field experiment.” American Political Science Review 102(1):33-48.

Gerkey, D. (2013). "Cooperation in Context: Public Goods Games and Post-Soviet Collectives in Kamchatka, Russia." Current Anthropology, 54(2): 144-176.

Gërxhani K. and A. Schram (2000). "Politics in Transition Economies: Consequences of a Clan Culture." Journal for Institutional Innovation, Development and Transition 4: 5-14.

Gërxhani K. and A. Schram (2009). "Clientelism and Polarized Voting: Empirical Evidence." Public Choice, 141: 305-317.

Glaeser, E., Laibson, D., Scheinkman, J., Soutter, C. (2000). “Measuring trust.” Quarterly Journal of Economics 115, 811-846.

Green, D. P., Gerber, A. S. and D. W. Nickerson (2003). "Getting Out the Vote in Local Elections: Results from Six Door-to-Door Canvassing Experiments.” Journal of Politics 65: 1083-96.

Grossman S. J. and O. Hart (1980). "Takeover Bids, The Free-Rider Problem, and the Theory of the Corporation.” The Bell Journal of Economics, Vol. 11, No. 1 (Spring, 1980), pp. 42-64.

Habyarimana, J., M. Humphreys, D. N. Posner, and J. M. Weinstein (2007). "Why Does Ethnic Diversity Undermine Public Goods Provision?” American Political Science Review, 101(4): 709-25.

Henrich, J., \& N. Smith (2004). "Comparative experimental evidence from Machiguenga, Mapuche, Huinca \& American populations shows substantial variation among social groups in bargaining and 
public goods behavior." In Foundations of Human Sociality: Economic Experiments and Ethnographic Evidence from Fifteen Small-Scale Societies, edited by Henrich, J., Boyd, R., Bowles, S., Gintis, H., Fehr, E. and Camerer, C. Oxford University Press.

Henrich, J., R. Boyd, S. Bowles, C. Camerer, E. Fehr, H. Gintis, R. McElreath, M. Alvard, A. Barr, J. Ensminger, K. Hill, F. Gil-White, M. Gurven, F. Marlowe, J. Q. Patton, N. Smith, and D. Tracer (2005). "Economic Man' in Cross-Cultural Perspective: Behavioral Experiments in 15 Small-scale Societies." Behavioral and Brain Sciences, 28(6): 795-815.

Hermann, B., Thöni, C., \& Gächter, S. (2008). "Antisocial punishments across societies.” Science, 319: $1362-1367$.

Huntington S. P. (1991). The Third Wave: Democratization in the Late Twentieth Century. Norman, OK, and London: University of Oklahoma Press.

Isaac, M. and J. Walker (1988). "Group size effects in public goods provision: The voluntary contribution mechanism." Quarterly Journal of Economics 103, 179-200.

Karlan, D. (2005). "Using Experimental Economics to Measure Social Capital and Predict Financial Decisions.” American Economic Review, 95(5): 1688-1699.

Lawson, C. and D. Saltmarshe (2000). "Security and Economic Transition: Evidence from North Albania." Europe-Asia Studies, 52 (1): 133-148.

Lewis, M. and G. Pettersson (2009). "Governance in health care delivery: raising performance". Policy Research Working Paper Series 5074, The World Bank.

Ledyard, O. (1995). "Public goods: some experimental results". In J. Kagel \& A. Roth (Eds.), Handbook of experimental economics. Princeton: Princeton University Press (Chap. 2).

Lipset, S. M. (1994). "The Social Requisites of Democracy Revisited: 1993 Presidential Address." American Sociological Review, 59 (1): 1-22.

Manski, C. F. (2004). “Measuring Expectations.” Econometrica, Vol. 72 (5): 1329-1376.

Miguel, E. and M. K. Gugerty (2005). "Ethnic diversity, social sanctions, and public goods in Kenya." Journal of Public Economics, 89(11-12): 2325-2368.

Morenoff, J., Sampson, R. J. and S. Raudenbush (2001). "Neighborhood Inequality, Collective Efficacy, and the Spatial Dynamics of Urban Violence." Criminology 39: 517-560.

Olson (1965). The logic of collective action. Cambridge: Harvard University Press

Ostrom, E. (1998). "A behavioral approach to the rational choice theory of collective action." The American Political Science Review, 92 (1): 1-22.

Paldam, M. and G. T. Svendsen (2000). "Missing Social Capital and the Transition in Eastern Europe." Working paper 00-5, Aarhus School of Business, Department of Economics.

Palfrey, T.R., and Rosenthal, H. (1983). “A strategic calculus of voting.” Public Choice 41: 7-53. 
Palfrey, T.R., and Rosenthal, H. (1985). "Voter participation and strategic uncertainty." American Political Science Review 79: 62-78.

Platteau J. P. (2008). "Pitfalls of participatory development." In Participatory Governance and the Millennium Development Goals, United Nations, New York.

Pradhan, M., Sryadarma, D., Beatty, A., Wong, M., Asishjabana, A., Gaduh, A. and R. P. Artha (2011). "Improving Educational Quality through Enhancing Community Participation Results from a Randomized Field Experiment in Indonesia.” Research Policy Working Paper 5795, The World Bank.

Putnam, R. (2000). Bowling Alone: The Collapse and Revival of American Community. New York: Simon \& Schuster.

Riker, W. and P. Ordeshook (1968). "A Theory of the Calculus of Voting." American Political Science Review 62(1): 25-42.

Rose R. (1993). "Rethinking Civil Society: Postcommunism and the Problem of Trust." Journal of Democracy 1(1): 18-29.

Rustagi, D., Engel, S. and Kosfeld, M. (2010). "Conditional Cooperation and Costly Monitoring Explain Success in Forest Commons Management." Science , 330, 961 - 965

Samuelson, Paul A. (1954). "The Pure Theory of Public Expenditure." Review of Economics and Statistics 36 (4): 387-389.

Sampson, R. J., D. McAdam, H. MacIndoe, and S. Weffer (2005). "Civil Society Reconsidered: The Durable Nature and Community Structure of Collective Civic Action." American Journal of Sociology 111: 673-714.

Serra, D., A. Barr and T. Packard (2011)."'Education outcomes, school governance and parents'demand for accountability : evidence from Albania." Policy Research Working Paper Series 5643, The World Bank.

Serra, D., P. Serneels and A. Barr (2011). "Intrinsic motivations and the non-profit sector: Evidence from Ethiopia." Personality and Individual Preferences, special issue on Economics and Psychology, vol. 51(3): 309-314.

Shala, A. (1997). The Albanian crisis - A view from within. A Transnational Institute publication, Den Haag, The Netherlands.

Smolar A. (1996). "Civil Society After Communism: From Opposition to Atomization." Journal of Democracy, 4 (1): 24-38.

Talifi N. (2008). “Consolidation of Democracy: Albania.” Journal of Political Inquiry, vol. 1.

World Bank (2004). World Development Report 2004: Making Services Work for Poor People. Oxford University Press, 2004. 


\section{APPENDIX}

\section{Table A1}

\begin{tabular}{lc}
\multicolumn{1}{c}{ Survey Question } & $\begin{array}{c}\text { 2009 School } \\
\text { Stakeholder } \\
\text { Survey }\end{array}$ \\
\hline $\begin{array}{l}\text { Measures of social engagement } \\
\text { Do you belong to any social clubs, community-based organizations, economic } \\
\text { organizations (such as microfinance groups), churches, mosques, or other social group } \\
\text { in the community? }\end{array}$ & $\checkmark$ \\
In the past year, did you or any in your household participate in any communal \\
activities, in which people came together to do some work for the benefit of the \\
community? \\
If there was a water supply problem, how likely is that people will cooperate to try to \\
solve the problem? (1-5 Likert scale) \\
$\begin{array}{l}\text { In general, do you believe that most people can be trusted, or do you think that you } \\
\text { can't be too careful? }\end{array}$
\end{tabular}


Table A2

School-level pair-wise correlations between parental participation and school outcomes

\begin{tabular}{|c|c|}
\hline & $\begin{array}{c}\text { \% participating } \\
\text { parents }\end{array}$ \\
\hline Students who got 10 in Math (\%) & $\begin{array}{l}\mathbf{0 . 1 4 4 4} * \\
(0.0573)\end{array}$ \\
\hline Students who got 10 in Albanian (\%) & $\begin{array}{l}\mathbf{0 . 1 3 9 9 *} \\
(0.0656)\end{array}$ \\
\hline Drop-out rate & $\begin{array}{l}-0.0628 \\
(0.4332)\end{array}$ \\
\hline Failure rate (in the final exam) & $\begin{array}{c}\mathbf{- 0 . 1 4 5 4} * \\
(0.0562)\end{array}$ \\
\hline Repetition rate & $\begin{array}{l}-\mathbf{0 . 1 2 4 6 *} \\
(0.0985) \\
\end{array}$ \\
\hline$\%$ parents unsatisfied with the school & $\begin{array}{c}\mathbf{- 0 . 2 4 8}^{* * * *} \\
(0.0008)\end{array}$ \\
\hline$\%$ parents perceiving embezzlement of construction funds & -0.1199 \\
\hline$\%$ parents perceiving embezzlement of scholarship funds & $\begin{array}{l}(0.1089) \\
\mathbf{- 0 . 1 3 3 2} * \\
(0.0748) \\
\end{array}$ \\
\hline
\end{tabular}




\section{Table A3}

Parental participation in schools and cooperation in the game by district

\begin{tabular}{lcc|lcc}
\hline District & $\begin{array}{c}\text { \% participating } \\
\text { parents }\end{array}$ & $\begin{array}{c}\text { \% cooperating } \\
\text { parents }\end{array}$ & District & $\begin{array}{c}\text { \% participating } \\
\text { parents }\end{array}$ & $\begin{array}{c}\text { \% cooperating } \\
\text { parents }\end{array}$ \\
\hline Delvine & $75 \%$ & $95 \%$ & Pogradec & $53 \%$ & $88 \%$ \\
Mat & $70 \%$ & $88 \%$ & Bulqize & $50 \%$ & $58 \%$ \\
Has & $68 \%$ & $85 \%$ & Gjirokaster & $48 \%$ & $90 \%$ \\
Fier & $67 \%$ & $67 \%$ & Mirdite & $48 \%$ & $68 \%$ \\
Kukes & $67 \%$ & $80 \%$ & Puke & $48 \%$ & $73 \%$ \\
Kurbin & $67 \%$ & $70 \%$ & Tepelene & $48 \%$ & $98 \%$ \\
Tirane & $66 \%$ & $76 \%$ & Kolonje & $45 \%$ & $90 \%$ \\
Kruje & $62 \%$ & $70 \%$ & Permet & $45 \%$ & $78 \%$ \\
Mallakaster & $60 \%$ & $75 \%$ & Lushnje & $43 \%$ & $47 \%$ \\
Sarande & $60 \%$ & $63 \%$ & Lezhe & $35 \%$ & $67 \%$ \\
Gramsh & $58 \%$ & $68 \%$ & M.Madhe & $33 \%$ & $83 \%$ \\
Kucove & $58 \%$ & $63 \%$ & Tropoje & $33 \%$ & $88 \%$ \\
Skrapar & $58 \%$ & $75 \%$ & Durres & $33 \%$ & $68 \%$ \\
Berat & $58 \%$ & $68 \%$ & Kavaje & $33 \%$ & $70 \%$ \\
Librazhd & $58 \%$ & Kore & $32 \%$ & $78 \%$ \\
Devoll & $55 \%$ & $98 \%$ & Peqin & $28 \%$ & $77 \%$ \\
Diber & $55 \%$ & $95 \%$ & Elbasan & $25 \%$ & $62 \%$ \\
Vlore & $55 \%$ & $80 \%$ & Shkoder & $18 \%$ & \\
\hline
\end{tabular}




\section{Table A4}

Framing effects

\begin{tabular}{|c|c|c|}
\hline & \multicolumn{2}{|c|}{$\begin{array}{l}\text { Dependent variable: } \\
\text { Dummy equal to } 1 \text { if the parent voted in the elections } \\
\text { of the class parent representatives, } 0 \text { otherwise }\end{array}$} \\
\hline & $\begin{array}{c}\text { Probit } \\
\text { (1) }\end{array}$ & $\begin{array}{c}\text { Probit -Restricted sample } \\
\text { (2) }\end{array}$ \\
\hline Invested in group account in the game & $\begin{array}{l}0.102 * * \\
(0.019)\end{array}$ & $\begin{array}{c}0.092^{* *} \\
(0.046)\end{array}$ \\
\hline Farming example in the game & $\begin{array}{l}-0.036 \\
(0.530)\end{array}$ & $\begin{array}{c}0.017 \\
(0.766)\end{array}$ \\
\hline Farming example $\mathrm{x}$ invested in the group account & $\begin{array}{l}-0.039 \\
(0.560) \\
\end{array}$ & $\begin{array}{l}-0.051 \\
(0.471) \\
\end{array}$ \\
\hline Age & $\begin{array}{c}0.003 \\
(0.132)\end{array}$ & $\begin{array}{c}0.002 \\
(0.421)\end{array}$ \\
\hline Female & $\begin{array}{l}0.059^{*} \\
(0.054)\end{array}$ & $\begin{array}{c}0.034 \\
(0.281)\end{array}$ \\
\hline Wealth index & $\begin{array}{c}0.044 * * \\
(0.017)\end{array}$ & $\begin{array}{c}0.018 \\
(0.292)\end{array}$ \\
\hline Years of schooling & $\begin{array}{c}0.025 * * * \\
(0.000)\end{array}$ & $\begin{array}{l}0.020 * * * \\
(0.000)\end{array}$ \\
\hline Rural location & $\begin{array}{c}-0.096 * * * \\
(0.007)\end{array}$ & $\begin{array}{l}-0.022 \\
(0.520)\end{array}$ \\
\hline Distance from school $(\mathrm{Km})$ & $\begin{array}{l}-0.004 \\
(0.679) \\
\end{array}$ & $\begin{array}{l}-0.004 \\
(0.636) \\
\end{array}$ \\
\hline Member of a social organization & $\begin{array}{l}0.162^{*} \\
(0.054)\end{array}$ & $\begin{array}{c}0.084 \\
(0.282)\end{array}$ \\
\hline Participation in community activities & $\begin{array}{c}0.119 * * * \\
(0.003)\end{array}$ & $\begin{array}{l}0.071^{*} \\
(0.062)\end{array}$ \\
\hline Think that community members would work together & $\begin{array}{c}0.034 \\
(0.264)\end{array}$ & $\begin{array}{c}0.076 * * \\
(0.029)\end{array}$ \\
\hline General trust in others & $\begin{array}{l}-0.079 * \\
(0.059)\end{array}$ & $\begin{array}{l}-0.036 \\
(0.429)\end{array}$ \\
\hline Number of relatives and friends among parents & $\begin{array}{c}0.012 \\
(0.276)\end{array}$ & $\begin{array}{l}0.008 \\
(0.396)\end{array}$ \\
\hline Help pupil with homework & $\begin{array}{l}-0.003 \\
(0.930)\end{array}$ & $\begin{array}{l}0.003 \\
(0.927)\end{array}$ \\
\hline Number of meetings with head teacher & $\begin{array}{l}0.015 * * * \\
(0.001)\end{array}$ & $\begin{array}{l}0.009 * \\
(0.070)\end{array}$ \\
\hline $\begin{array}{l}\text { District fixed effects } \\
\quad \text { Joint significance of district f.e. (p-value) }\end{array}$ & $\begin{array}{c}\text { YES } \\
<0.001 * * *\end{array}$ & $\begin{array}{c}\text { YES } \\
<0.001 * * *\end{array}$ \\
\hline Observations & 1,800 & 1,302 \\
\hline
\end{tabular}




\section{Experimental Instructions}

\section{The Public good game}

\section{PRESENTATION TO THE GROUP}

We are now ready to begin playing a game that will involve all of you. Each one of you will make his or her decision alone and in private, at the same time as everyone else. Based on the decision that you and the other participants in the game make, this game could earn you between 100 and 1900 LEK, although it is rare for people to earn 1900 LEK.

The decision that you make in this game is strictly confidential; in order to guarantee confidentiality we ask you not to communicate with each other at any time during the game. If you talk to each other we will have to stop the game and nobody will get any money from the workshop.

At the start of this game each of you will receive a voucher. The each of you has to decide whether to invest the voucher in:

- a PRIVATE Account (P)

or

- a GROUP Account $(\mathrm{G})$

If you invest your voucher in the GROUP Account you will receive 100 LEK for every voucher that you and the other participants have invested in the GROUP Account.

If you invest your voucher on the Private Account your earnings will be determined as follows: first you will receive a fix private return of 500 LEK; second, you will also receive 100 LEK for every voucher that the other participants have decided to invest in the GROUP Account.

You will soon receive a voucher like this one on the board, only smaller. At the bottom of the voucher you will see two big letters: a letter P and a letter G. The letter P, on the left, stands for "Private Account"; the letter G, on the right, stands for "GROUP Account". If you want to invest your voucher in a Private Account you must to draw a circle around the letter P. If you want to invest your voucher in the GROUP Account you must draw a circle around the letter G. We will now go through some examples.

1. Suppose that you invest your voucher in the GROUP Account, which means that you circled the letter S on your voucher. [Write the letter $P$ on the left of the board, and the letter $G$ on the right, in capital letters, as in the voucher. Then, circle the letter G]. And suppose that everyone invested their voucher in the GROUP Account. [Write 15 below the letter $G$ and 0 below the letter P].

Then you and the each of the other participants will receive 100x15=1500 LEK from this game.[Write $100 \times 15=1500$ in a box on the right of the number 15, below the letter G. Link the number 15 and the box with an arrow]

2. Suppose that you invest your voucher in the GROUP Account, which means that you circled the letter $\mathrm{S}$ on your voucher. [Point the letter $G$ on the board, that you have circled before] And suppose that, in total, two people invested their vouchers in Private Accounts and 13 people, you and 12 others, invested in the GROUP Account. [Write the number 2 below the letter $P$ and the number 13 below the letter G]. Then you and the other participants who invested in the GROUP Account would each receive 100x13=1300 LEK [write this amount in 
a box on the right of the number 13, as before] from this game, and each of the participants who invested their vouchers in the Private Account will each receive 1300 LEK from the GROUP Account PLUS 500 LEK from their Private Account, making a total of 1800 LEK. [write this amount on the left of the number 2, in a box, as before]

3. Suppose that you invest your voucher in a Private Account, which means that you circled the letter P on your voucher. [Now, circle the letter P]. And suppose that, in total, 10 people, you and 9 others, invested their vouchers in Private Accounts [write 10 under the letter P] and 5 people invested in the GROUP Account. [Write 5 under the letter $G$ ]. Then, each of the participants who invested their vouchers in the GROUP Account will receive 100x5=500 LEK from this game [Write this amount in a box on the right of the number 5] and you and each of the other people who invested in a Private Account will receive 500 LEK from the GROUP Account PLUS 500 LEK from your Private Account, making a total of 1000 LEK. [Write this amount in a box on the left of the number 10, as before]

4. Suppose that you invest your voucher in a Private Account, which means that you circled the letter P on your voucher. And suppose that everyone invested their vouchers in Private Accounts. Then, since nobody invested in the GROUP Account, nobody gets anything from that account and everybody goes home with the 500 LEK from their Private Account.

Is it clear to everybody?

Remember that if you invest in the Group Account you get (100 x Number of people who invested in the Group Account). If instead you invest in the Private Account you get (100 x Number of people who invested in the Group Account +500$)$.

Let's go through more examples.

Can you answer the following questions?

5. Suppose that in total, 5 people invested their vouchers in Private Accounts. How many people invested in the Group Account? (10) [After people answer the question, write the number 5 below the letter $P$ and the number 10 below the letter G]. Then, how much did the people who invested in the Group Account get? $(100 \times 10=$ 1000) [After people answer the question, write this amount in a box on the right of the number 10, as before]. And how much did the people who invested in the Private Account get? $(500+1000=1500)$ [After people answer this question, write this amount on the left of the number 5, in a box, as before]

6. Suppose that in total, 7 people invested their vouchers in Private Accounts. How many people invested in the Group Account? (8) [After people answer the question, write the number 7 below the letter $P$ and the number 8 below the letter $G]$. Then, how much did the people who invested in the Group Account get? $(100 \times 8=800)$ [After people answer the question, write this amount in a box on the right of the number 8 , as before]. And how much did the people who invested in the Private Account get? $(500+800=1300)$ [After people answer this question, write this amount on the left of the number 7 , in a box, as before]

7. Suppose that in total, 14 people invested their vouchers in Private Accounts. How many people invested in the Group Account? (21 [After people answer the question, write the number 14 below the letter $P$ and the number 1 below the letter G]. Then, how much did the people who invested in the Group Account get? $(100 \times 1=100)$ [After people answer the question, write this amount in a box on the right of the number 1, as before]. And how much did the people who invested in the Private Account get? $(500+100=600)$ [After people answer this question, write this amount on the left of the number 14, in a box, as before] 
Is this all clear to everybody now? Are you sure?

Remember that all the participants benefit from the vouchers invested in the GROUP Account, whereas only you benefit from the voucher invested in the Private Account.

This game is designed to simulate a type of dilemma that many of us find ourselves in at various points in our lives. For example:

[School Example: Imagine a community with its own primary school. After finishing primary school, the children go to secondary schools elsewhere and imagine a situation where only children who perform well in the final test sat in year 9 can get a scholarship. If all the parents invest resources, including time and effort, to make sure that the primary school runs well, all the children are likely to learn while in school and do well in the exam, which means that they all have a good chance of getting into the best secondary school. However, each parent knows that even if he does not invest his resources in the school, other parents are likely to do so; therefore his child will benefit anyway while he will still have resources to invest privately for his child, for example by paying for private lessons. So, each parent faces an incentive to keep their resources and not invest in the school; however, if all the parents decide not to invest in the school, the school will not perform well and their child's success will depend solely on their private investment in the child's education.

So, like in the game, the dilemma for each parent is:-

- Invest in the school and benefit all children but face the risk of being the only parent investing resources in the school, and therefore being taken advantage of by the other parents

Or

- Do not invest in the school in the hope that someone else will, bearing in mind that if all parents decide not to contribute to the school all the children will be disadvantaged]

[Farming Example: Imagine a village where a group of farmers share a water pump. If the pump breaks all of them get less water to their land. When the pump breaks, the ideal situation is for all the farmers to spend resources, including time and effort, to repair it immediately and the more of them put together resources to repair the pump the easier and quicker the mending is. However, each farmer knows that even if he does not contribute to the mending of the pump, other farmers are likely to do so. So, each farmer faces an incentive not to contribute to the mending of the pump; however if all the farmers decide not to contribute to the mending of the pump, the pump is left broken and they all suffer.

So, like in the game, the dilemma for each farmer is:-

- Contribute to the mending of the pump and benefit all farmers, but face the risk of being the only one contributing and therefore being taken advantage of by the other farmers

Or

- $\quad$ Do not contribute to the mending of the pump in the hope that someone else will, bearing in mind that if all the farmers decide not to contribute, everyone will suffer 
Remember that we have designed this game so that the other participants in the game will never know the decisions that each of you make. The only information that we will give to all participants at the end of the game is the total number of people who invested in the GROUP Account.

We are now going to distribute one voucher to each of you. Your color and player number is written at the top. At the bottom of the voucher you will see a letter P and a letter G, just like here on the board. If you want to invest the voucher in a Private Account, you must draw a circle around the letter P. If you want to invest the voucher in the GROUP Account, you must draw a circle around the letter G.

Are there any questions on how to play this game?

[Distribute vouchers]

Please check your color and player number on the voucher. If these are not right we will not be able to pay you correctly for the game.

Then circle either the $\mathrm{P}$ or the G. When you are done please fold the voucher. Then raise your hand and [name of $R A]$ will come and collect your voucher. 